\title{
Review \\ Plants known as té in Spain: An ethno-pharmaco-botanical review ${ }^{\text {is }}$
}

\author{
Manuel Pardo de Santayana*, Emilio Blanco, Ramón Morales \\ Real Jardín Botánico (CSIC), Plaza de Murillo 2, E-28014 Madrid, Spain
}

Accepted 16 November 2004

\begin{abstract}
Although the word té (tea) in Spanish is derived from the Chinese tscha and refers to the oriental plant Camellia sinensis, it is popularly used throughout Spain to refer to at least 70 different plant species. These are usually collected in the countryside, boiled dry or fresh, and drunk after meals. The drinking of té is a social habit that encourages conversation in a relaxed atmosphere. Tés are also commonly used as digestifs and stomachics, and in some cases as laxatives, antidiarrhoeics, and to reduce the blood pressure. They are not used as stimulants. It appears that the habit of drinking Camellia sinensis afforded the cognitive context for drinking other infusions with no specific medicinal purpose. Some té species are very common in Spain (and their use is quite extended), others are endemic, and others still are allochthonous that now live in the wild. The majority of these species belong to the families Asteraceae and Lamiaceae. The most important and widely distributed are Jasonia glutinosa, Sideritis hyssopifolia, Lithospermum officinale, Chenopodium ambrosioides and Bidens aurea. Other remarkable but more locally used tés include Cruciata glabra (only in the Pyrenees), Inula salicina and Mentha arvensis (in the Central Mountain Range of Madrid), and Potentilla caulescens (in Tarragona).
\end{abstract}

(C) 2004 Elsevier Ireland Ltd. All rights reserved.

Keywords: Digestive infusions; Digestifs; Folk nomenclature; Nutraceuticals; Traditional food; Traditional medicine

\section{Contents}

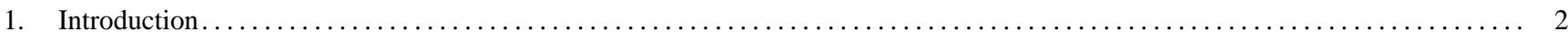

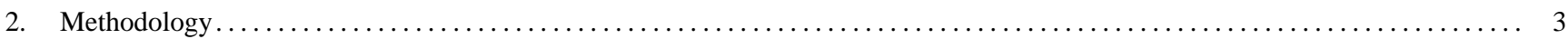

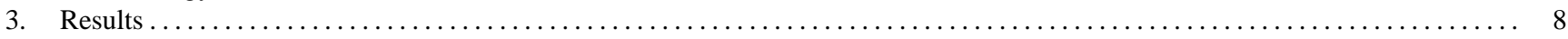

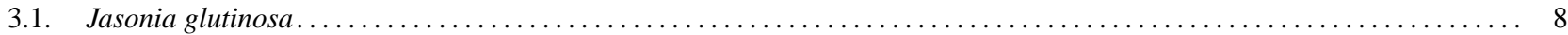

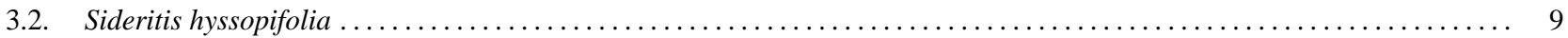

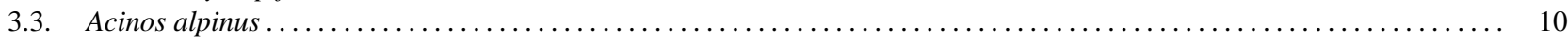

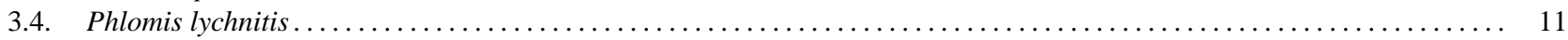

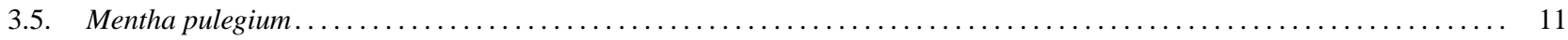

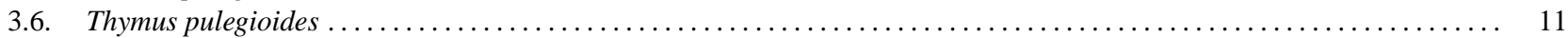

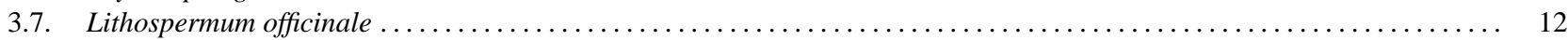

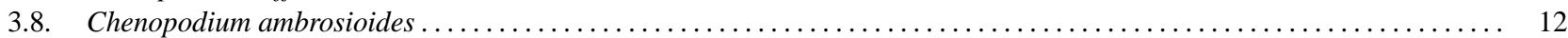

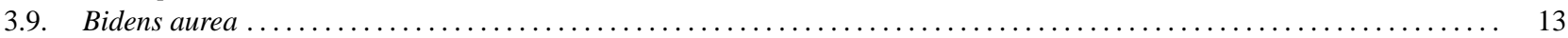

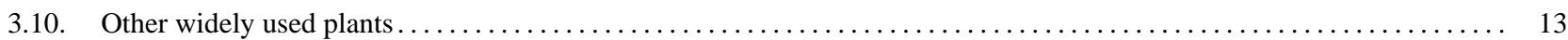

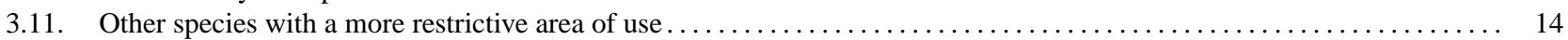

\footnotetext{
The aim of this paper is to highlight the relevance of plants called té. They include some of the most popular medicinal Spanish species, many of them still very commonly gathered and even marketed, mainly used as digestifs. Many of these species have a very high informant consensus and are also consumed as social beverages. Many pharmacological studies have indicated that most of them have digestive properties.

* Corresponding author. Tel.: +34 91 4203017; fax: +34 914200157.

E-mail address: mpardo@ma-rjb.csic.es (M. Pardo de Santayana).
} 


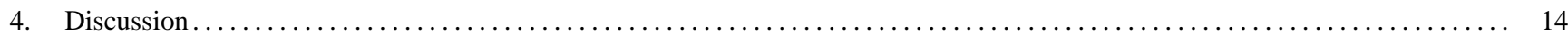

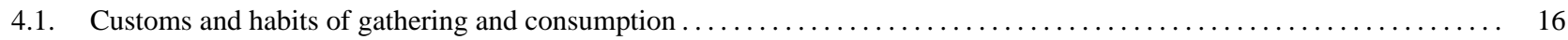

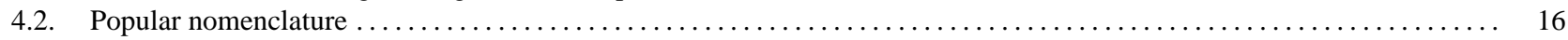

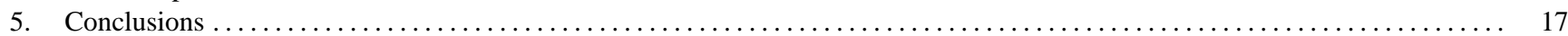

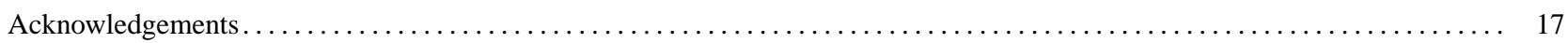

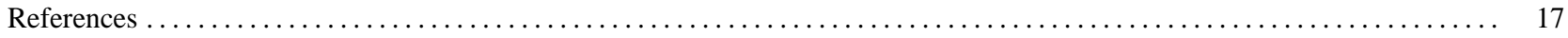

\section{Introduction}

The Spanish word té, like tea in English, Tee in German, tè in Italian and thé in French, comes from the Chinese tscha (pronounced "tai", "cá" or "chai"). The term eventually entered into use in Japanese, Hindi, Turkish, Russian and Portuguese. Indeed, the names given to Camellia sinensis (L.) Kuntze (Theaceae) in most languages stem from the original Chinese.

It seems that tea was introduced into Europe by the Dutch East India Company at the beginning of the seventeenth century, under the name thee. In 1666, it was taken to England by Arlington and Ossory (Kazuko, 1944). The Portuguese introduced it into their country where it became known as cha-more similar to the Chinese word. The remaining European languages, including Spanish, usually incorporated the word as a derivative of thee. The species' first scientific name was Thea sinensis $\mathrm{L}$.

In English and Latin American Spanish, the term 'tea' can mean an infusion prepared with Camellia sinensis leaves and boiling water, or any other infusion prepared with herbs. The popular meaning of té in Spain is not so wide: it is not usually used as a synonym of infusion, although it is applied to a great number of herbs used to make digestifs and stomachics, as well as regular tea made with Camellia sinensis. Té is also used to refer to certain plants with no digestive properties at all, and to the infusions prepared with them. As an example of the folk meaning of the term té, a shepherd from Broto (Huesca) is recorded as identifying Armeria alpina as té, the use of the term being linked to this species' preparation as an infusion for its digestion-aiding properties (Villar et al., 1987).

The consumption of Camellia sinensis is not tremendously popular in Spain, especially in rural areas. In fact, in many Spanish rural regions people use expressions such as "bag tea" to refer to Camellia sinensis; to them, té is a term best applied to other species such as Jasonia glutinosa or Sideritis hyssopifolia. Font Quer (1962) relates an interesting story that occurred in 1934 in San Carlos de la Rápita (Catalonia), when he, Braun-Blanquet and a number of other botanists asked for tea at breakfast; and were served an infusion of Jasonia glutinosa. He asked the innkeeper what kind of tea this was; the reply he received was: "Tea, the best tea, rock tea!".

Numerous ethnopharmacological surveys record that gastrointestinal disorders are the main concern of many popular pharmacopoeias around the world (see Ankli et al., 1999; Bonet, 2001; Pardo de Santayana, 2003; Scarpa, 2004). Most of the plants used to treat gastrointestinal problems help the process of digestion, and many have known pharmacological properties that make this possible: their bitter-tasting ingredients stimulate the flow of saliva and the secretion of gastric juices; other substances act as anti-inflammatory agents or analgesics at the gastric mucosa; antacids (e.g., mucilage) help neutralize stomach acidity either mechanically or chemically; certain compounds with antispasmodic activity may help avoid excessive intestinal peristalsis while others may produce the opposite effect, helping the food bolus move along by stimulating rhythmical contractions of the gut wall; certain antiseptic compounds help prevent unwanted fermentations that lead to foul smelling faeces; choleretic and cholagogic ingredients stimulate both the production and secretion of bile (which provides the classic colour to faeces and encourages stool firmness); and finally, carminative agents help to eliminate air from the digestive tract.

About 130 plant species have been traditionally gathered in Spain for preparing digestive infusions (J. Tardío personal communication), about half of which are known as té. Another important group of digestive herbal teas goes by the name of manzanilla (camomile), which in its strictest sense refers only to Matricaria recutita L. and Chamaemelum nobile (L.) All. (Asteraceae), but popularly covers more than 20 species. It is not easy to say why people should consider some plants with digestive properties to be described under the generic term manzanilla while others are classed as té. However, tés are usually beverages drunk for their pleasant flavour quite apart from their facilitating digestion. Manzanillas, on the other hand, which are usually made from ligulate Anthemideae or other Asteraceae, are usually taken for their cholagogic and choleretic properties. Another large group is formed by the poleos or mentas (more than 20 species). Strictly speaking the term refers to species of the genus Mentha, but it is also applied to many other members of the Lamiaceae family that have a minty smell, such as Calamintha nepeta or Lycopus europaeus.

This paper compiles the available information on the common names and uses of all plants in Spain that fall under the popular term té; common properties of these species were also sought. Some of the most popular Spanish medicinal plants are included among the tés (e.g., Jasonia glutinosa, 
Mentha pulegium, Sideritis hyssopifolia) and their pharmacological evaluation is of particular interest. Other Spanish researchers have also shown interest in these plants known as té. For example, for 10 species in Aragón, Villar (2003) compiled 45 names derived from té. All these plants appeared to be used for helping the process of digestion.

\section{Methodology}

Spanish botanical, ethnobotanical and ethnopharmacological (Fig. 1) studies of the last 25 years were systematically surveyed (see references in Table 1) to obtain information on the use of plants popularly known as té or identified with binomials that include the term té plus an epithet (e.g., té amarillo, yellow tea). We also took into account; for comparative purposes, all plants used to prepare digestive infusions. The survey included the examination of regional floras (Bolòs and Vigo, 1984-2001; Mateo, 1990), dictionaries of vernacular names (Masclans, 1981; Calero, 1989; Esgueva, 1999), general works on Spanish medicinal plants (Font Quer, 1962; Peris et al., 2001), regional ethnobotanical studies (Obón and Rivera, 1991; Mulet, 1991) and local studies (Mesa, 1996; San Miguel, 2004).

Our own published and unpublished original data (Blanco, 1996, 1998, 2002; Blanco and Cuadrado, 2000; Tardío et al., 2002; Pardo de Santayana, 2003; San Miguel, 2004) recorded over years of field work throughout Spain were also examined.

This ethnopharmacobotanical, linguistic and historical approach was used given the power of such interdisciplinary methodology (see Leonti et al., 2003; RamónLaca, 2003). The popular names and uses of plants were recorded and analysed in terms of their geographical distribution. Their medicinal and pharmacological properties, and the interaction between popular nomenclature and plant use were also recorded. We also sought historical information on the most important plants in order to determine the antiquity of their popular use (Laguna, 1555; l'Ecluse, 1576; Cienfuegos, c. 1620; Quer, 1762-1764; Palau, 1784-1788; Cavanilles, 1802; Loscos and Pardo, 1867).

The most important species were regarded as those used in the greatest number of areas and those with the highest frequency of citation, i.e., by the number of people who used them in each area. Strong agreement regarding the use of plants has previously been considered a measure of their medicinal properties and efficacy (Trotter and Logan, 1986; Heinrich, 2000). It was not always possible to exactly determine the frequency of citation since the papers reviewed were not homogeneous and many did not clearly indicate the extent of use.

Voucher specimens of the studied plants were deposited at the Herbarium of the Real Jardín Botánico, CSIC (MA).

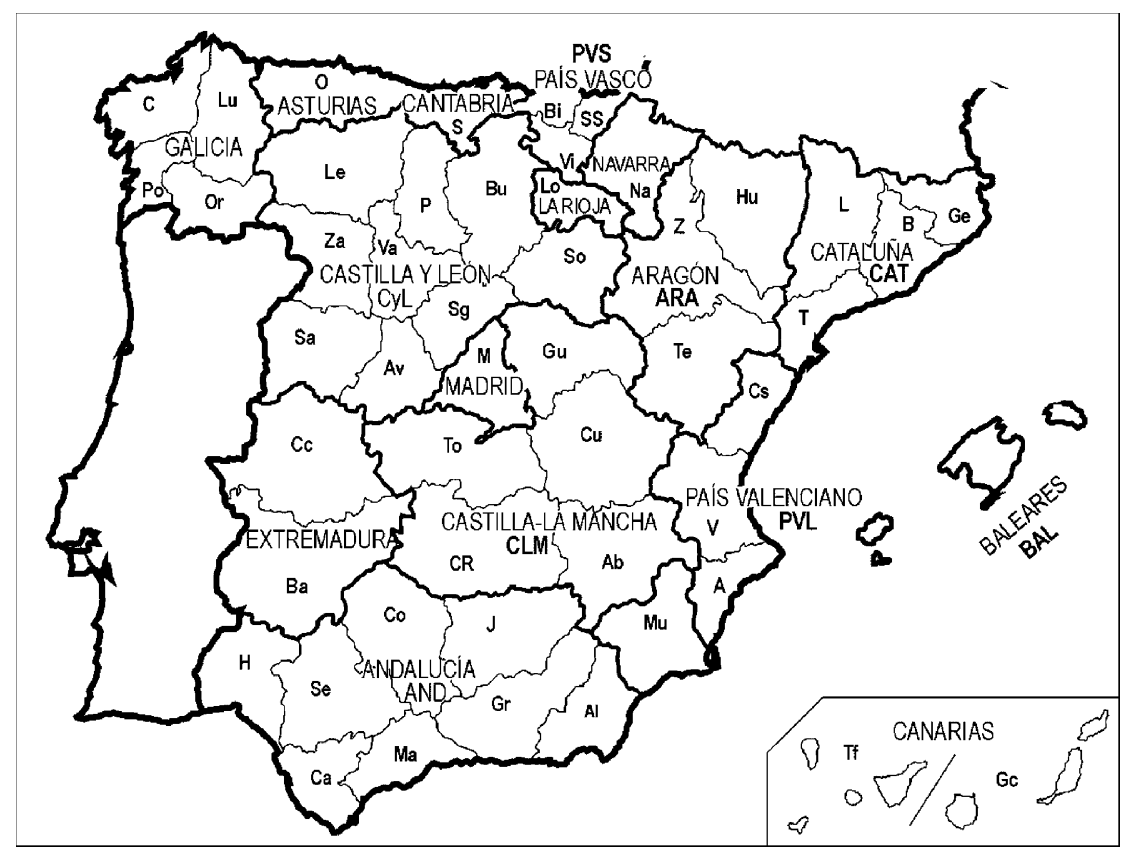

Fig. 1. Study area. Names and abbreviations of Spanish provinces: A, Alicante; Ab, Albacete; Al, Almería; Av, Ávila; B, Barcelona; Ba, Badajoz; Bi, Vizcaya; Bu, Burgos; C, La Coruña; Ca, Cádiz; Cc, Cáceres; Co, Córdoba; CR, Ciudad Real; Cs, Castellón; Cu, Cuenca; Gc, Gran Canaria; Ge, Gerona; Gr, Granada; Gu, Guadalajara; H, Huelva; Hu, Huesca; J, Jaén; L, Lérida; Le, León; Lo, La Rioja; Lu, Lugo; M, Madrid; Ma, Málaga; Mu, Murcia; Na, Navarra; O, Asturias; Or, Orense; P, Palencia; Po, Pontevedra; S, Cantabria; Sa, Salamanca; Se, Sevilla; Sg, Segovia; So, Soria; SS, Guipúzcoa; T, Tarragona; Te, Teruel; Tf, Tenerife; To, Toledo; V, Valencia; Va, Valladolid; Vi, Álava; Z, Zaragoza; Za, Zamora. Abbreviations of Spanish regions: AND, Andalucía; ARA, Aragón; BAL, Baleares; CyL, Castilla y León; CLM, Castilla-La Mancha; CAT, Cataluña; PVL, País Valenciano; PVS, País Vasco. 
Table 1

Species known as té in Spain and the areas in which they are consumed as digestive beverages

\begin{tabular}{|c|c|c|c|c|}
\hline Scientific name & Vernacular names derived from té & Area of use & Popular use & Reference \\
\hline \multicolumn{5}{|l|}{ ASTERACEAE } \\
\hline Achillea millefolium $\mathrm{L}$. & té purgante & $\mathrm{Hu}$ & $\begin{array}{l}\text { Digestif, laxative, febrifuge, } \\
\text { treatment for bronchitis, diuretic }^{\text {a }}\end{array}$ & Villar et al., 1987 \\
\hline Artemisia verlotiorum Lamotte & té & $\mathrm{CR}$ & Digestif $^{\mathrm{a}}$ & Verde et al., 2000 \\
\hline $\begin{array}{l}\text { Bidens aurea (Aiton) Sherff } \\
\text { (388MP) }\end{array}$ & $\begin{array}{l}\text { té, té americano, té chino, té } \\
\text { castellano, té de Buenos Aires, té de } \\
\text { huerta, té de huerto, té de Méjico, té } \\
\text { de Canarias, té moro, té moruno }\end{array}$ & Most regions & $\begin{array}{l}\text { Digestif, sedative, slimming, } \\
\text { antidiarrhoeic, headache treatment }\end{array}$ & $\begin{array}{l}\text { Blanco, 1996; Blanco, 1998; Pérez de } \\
\text { Paz and Medina, 1988; Rivera et al., } \\
\text { 1994; Blanco and Cuadrado, 2000; } \\
\text { Verde et al., 2000; Molina Mahedero, } \\
\text { 2001; Blanco, 2002; Tardío et al., } \\
\text { 2002; Pardo de Santayana, 2003; E. } \\
\text { Blanco personal observation }\end{array}$ \\
\hline $\begin{array}{l}\text { Conyza canadensis (L.) Cronq. } \\
\text { (318EBC) }\end{array}$ & té & $\mathrm{Gu}, \mathrm{M}$ & Digestif & E. Blanco personal observation \\
\hline Erigeron acer $\mathrm{L}$. & té de ribàs & Cs & Digestif & Mulet, 1991 \\
\hline $\begin{array}{l}\text { Helichrysum italicum (Roth) G. } \\
\text { Don }\end{array}$ & té del campo & $\mathrm{J}$ & Digestif, anticatarrhal agent ${ }^{\mathrm{a}}$ & Fernández Ocaña, 2000 \\
\hline $\begin{array}{l}\text { Helichrysum stoechas }(\mathrm{L} .) \\
\text { Moench (1717MP) }\end{array}$ & té & $\mathrm{Bu}, \mathrm{PVS}$ & Digestif $^{\mathrm{a}}$ & E. Blanco personal observation \\
\hline Inula montana $\mathrm{L}$. & té de caliza & M & Digestif & Tardío et al., 2002 \\
\hline Inula salicina $\mathrm{L}$. & té, té de prado & M & Digestif, antidiarrhoeic & Tardío et al., 2002 \\
\hline $\begin{array}{l}\text { Jasonia glutinosa }(\text { L.) DC. [syn.: } \\
\text { Chiliadenus glutinosus }(\mathrm{L} .) \\
\text { Fourr., Chiliadenus saxatilis } \\
\text { (Lam.) Brullo] (1775MP) }\end{array}$ & $\begin{array}{l}\text { hierba de té, la té, lo té, té, té } \\
\text { americano, té borde, té de Aragón, té } \\
\text { de caliza, té de carbonera, té de ceño, } \\
\text { té de glera, té de Gratal, té de } \\
\text { montaña, té de monte, té de peña, té } \\
\text { de piedra, té de ralla, té de risca, té de } \\
\text { risco, té de roca, té de sierra, té del } \\
\text { campo, té manzanilla, té moruno, té } \\
\text { roquer }\end{array}$ & $\begin{array}{l}\text { AND, ARA, BAL, CAT, } \\
\text { CLM, CyL, Lo, M, PVL, } \\
\text { PVS, S }\end{array}$ & $\begin{array}{l}\text { Digestif, anticatarrhal agent, sedative, } \\
\text { diuretic, antidiarrhoeic, analgesic }\end{array}$ & $\begin{array}{l}\text { Loscos and Pardo, 1867; Font Quer, } \\
\text { 1962; Bonafé, 1980; Villar et al., } \\
\text { 1987; Barandiarán and Manterola, } \\
\text { 1990; González-Tejero, 1990; Mulet, } \\
\text { 1991; Obón and Rivera, 1991; } \\
\text { Muntané, 1994; Climent, 1992; } \\
\text { Ferrández and Sanz, 1993; Mesa, } \\
\text { 1996; Guzmán Tirado, 1997; Blanco, } \\
\text { 1998; Fajardo et al., 2000; Fernández } \\
\text { Ocaña, 2000; Bonet, 2001; Fresquet } \\
\text { et al., 2001; Tardío et al., 2002; Pardo } \\
\text { de Santayana, 2003; Verde, 2003; E. } \\
\text { Blanco, R. Morales, M. Pardo de } \\
\text { Santayana, personal observations }\end{array}$ \\
\hline Jasonia tuberosa (L.) DC. & $\begin{array}{l}\text { té, té de burro, té de campo, té de las } \\
\text { viñas, té de tierra, té de montaña, té } \\
\text { de piedra, té de glera }\end{array}$ & $\mathrm{Gu}, \mathrm{Hu}, \mathrm{M}, \mathrm{Sg}$, & $\begin{array}{l}\text { Digestif, carminative, to lower blood } \\
\text { pressure }\end{array}$ & $\begin{array}{l}\text { Villar et al., 1987; Ferrández and } \\
\text { Sanz, 1993; Gil Pinilla, 1995; } \\
\text { Blanco, 1998; Tardío et al., } 2002\end{array}$ \\
\hline Phagnalon saxatile (L.) Cass. & té de piedra & $\mathrm{J}$ & $\begin{array}{l}\text { Carminative, analgesic, to lower } \\
\text { blood cholesterol levels }{ }^{\mathrm{a}}\end{array}$ & Fernández Ocaña, 2000 \\
\hline
\end{tabular}

blood cholesterol levels ${ }^{\mathrm{a}}$ 


\section{BORAGINACEAE}

Lithospermum officinale $\mathrm{L}$.

\section{CARYOPHYLLACEAE}

Paronychia argentea Lam.

\section{CHENOPODIACEAE}

Chenopodium ambrosioides $\mathrm{L}$.

(668EBC)

\section{CISTACEAE}

Helianthemum cinereum (Cav.)

Pers.

Helianthemum syriacum (Jacq.)

Dum. Cours.

CLUSIACEAE

Hypericum perforatum $\mathrm{L}$.

(156MP)

FABACEAE

Trigonella caerulea (L.) Ser.

\section{GERANIACEAE}

Erodium petraeum (Gouan) Willd.

\section{LAMIACEAE}

Acinos alpinus (L.) Moench

Acinos arvensis (Lam.) Dandy té de Penyagolosa

té, té blanco, té de acequia, té de barranco, té de Benasque, té de camí, té de grano, té de huerta, té de la Vírgen, te de mill, té de Miranda, té de perla, te de planter, te de prat, té fino, té negro, té perladuna, té purgante

té de campo, té de roca, te de roca blanc

té, té borde, té burrero, té de Argentina, té de España, té de Europa, té de Méjico, té de

Montserrat, té de Nueva España, té español, té falso, té hormigoso, té hormiguero, té rico, té silvestre, té verde

té de monte

té moro, té del campo, té de monte

té borde, té de montaña, té de tila, té de viña, té pericón

te dels horts

,é de campo, té de huerta, té de lastra, té de Mágina, té de monte, té de rastra, té de roca, té de sierra, té de Sierra Nevada, té de tierra, té fino
ARA, L, S

Digestif, antidiarrhoeic, litholytic, diuretic, anticatarrhal agent, headache treatment

$\mathrm{Cc}, \mathrm{Lu}, \mathrm{Mu}, \mathrm{Sa}, \mathrm{Za}$ ebrifuge

Digestif, laxative

Digestif

Digestif, febrifuge

Digestif, to lower blood pressure, sedativea $^{a}$

Digestif, anticatarrhal agent,

headache treatment

Carminative, stimulant, anticatarrhal agent, to lower blood pressure

Digestif, aperitif, antidiarrhoeic, slimming, anticatarrhal agent,

diuretic, to lower blood cholesterol

Digestif observation

Loscos and Pardo, 1867; Font Quer, 1962; Villar et al., 1987; Ferrández and Sanz, 1993; Agelet, 1999; Pardo

de Santayana, 2003

Muntané, 1994; Guzmán Tirado, 1997

Font Quer, 1962; Rivera et al., 1994; Blanco, 1996; Panero and Sánchez, 2000; E. Blanco personal observation

\section{Fajardo et al., 2000}

Verde et al., 1998; Fajardo et al., 2000; Fernández Ocaña, 2000

Mulet, 1991; E. Blanco personal observation

Agelet, 1999

Mulet, 1991

Font Quer, 1962; González-Tejero, 1990; Gil Pinilla, 1995; Mesa, 1996 ; Guzmán Tirado, 1997; Martínez Lirola et al., 1997; Verde et al., 1998; Fajardo et al., 2000; Fernández Ocaña, 2000

Verde et al., 1998; Fajardo et al., 2000 


\begin{tabular}{|c|c|c|c|c|}
\hline Scientific name & Vernacular names derived from té & Area of use & Popular use & Reference \\
\hline Calamintha nepeta (L.) Savi & $\begin{array}{l}\text { té, té de Granada, té de huerta, té de } \\
\text { vega, té del campo }\end{array}$ & $\mathrm{Ab}, \mathrm{Gr}$ & $\begin{array}{l}\text { Digestif, anticatarrhal agent, } \\
\text { antisudorific }\end{array}$ & $\begin{array}{l}\text { González-Tejero, 1990; Verde et al., } \\
1998\end{array}$ \\
\hline Lavandula stoechas $\mathrm{L}$. & té de moro & Cs, V & $\begin{array}{l}\text { Digestif, anticatarrhal agent, } \\
\text { antidiarrhoeic, stimulant }{ }^{\mathrm{a}}\end{array}$ & Mulet, 1991; Pellicer, 2000 \\
\hline Melissa officinalis $\mathrm{L}$. & té, té de calazo, té de huerto & GR, Hu & $\begin{array}{l}\text { Digestif, antidiarrhoeic, carminative, } \\
\text { headache treatment, sedative }{ }^{b}\end{array}$ & $\begin{array}{l}\text { Villar et al., 1987; González-Tejero, } \\
1990\end{array}$ \\
\hline Mentha aquatica $\mathrm{L}$. & $\begin{array}{l}\text { té, té bravo, té de río, té de vega, té } \\
\text { del Guadiana, té de prado, té moruno, } \\
\text { té poleo de río }\end{array}$ & $\mathrm{Ab}, \mathrm{Cu}, \mathrm{Sg}$ & Digestif $^{\mathrm{a}}$ & $\begin{array}{l}\text { Blanco, 1998; Fajardo et al., 2000; } \\
\text { Verde, } 2003\end{array}$ \\
\hline Mentha arvensis $\mathrm{L}$. & té del río & $\mathrm{M}$ & Digestif & Tardío et al., 2002 \\
\hline Mentha longifolia (L.) Huds. & té silvestre & $\mathrm{Cu}$ & Digestif & Verde, 2003 \\
\hline Mentha pulegium $\mathrm{L}$. & $\begin{array}{l}\text { té, té de balsa, té de charca, té de } \\
\text { menta, té de prao, té de rambla, té de } \\
\text { rodeno, té del campo, té poleo }\end{array}$ & $\mathrm{Ab}, \mathrm{Cu}, \mathrm{Gr}, \mathrm{Sg}$ & $\begin{array}{l}\text { Digestif, antidiarrhoeic, diuretic, } \\
\text { slimming, anticatarrhal agent }{ }^{\mathrm{c}}\end{array}$ & $\begin{array}{l}\text { González-Tejero, 1990; Blanco, } \\
\text { 1998; Verde et al., 1998; Fajardo et } \\
\text { al., 2000; Verde, } 2003\end{array}$ \\
\hline Mentha x piperita $\mathrm{L}$. & té de menta & $\mathrm{O}$ & Digestif & San Miguel, 2004 \\
\hline Micromeria fruticosa (L.) Druce & té poleo & $\mathrm{Cs}, \mathrm{Cu}$ & $\begin{array}{l}\text { Digestif, laxative, carminative, to } \\
\text { lower blood pressure, vulnerary, } \\
\text { anticatarrhal agent, aphrodisiac }\end{array}$ & Mulet, 1991; Verde, 2003 \\
\hline $\begin{array}{l}\text { Micromeria graeca }(\mathrm{L} .) \text { Benth. ex } \\
\text { Rchb. }\end{array}$ & $\begin{array}{l}\text { té de piedra, té moro, té moruno, té } \\
\text { silvestre }\end{array}$ & $\mathrm{J}, \mathrm{Co}$ & $\begin{array}{l}\text { To treat gastric ulcers, anticatarrhal } \\
\text { agent, febrifuge }\end{array}$ & $\begin{array}{l}\text { Molina Mahedero, 2001; Casado, } \\
2003\end{array}$ \\
\hline Nepeta nepetella $\mathrm{L}$. & té, té de glera, té fuerte & $\mathrm{Hu}$ & Digestif & Villar et al., 1987 \\
\hline Phlomis lychnitis L. (MA596768) & $\begin{array}{l}\text { té, té de campo, té de lastra, té de } \\
\text { monte, té de pastor, té moruno }\end{array}$ & $\mathrm{Ab}, \mathrm{CR}, \mathrm{Hu}, \mathrm{Sg}$ & Digestif, sedative ${ }^{\mathrm{a}}$ & $\begin{array}{l}\text { Villar et al., 1987; Blanco, 1998; } \\
\text { Fajardo et al., 2000; E. Blanco } \\
\text { personal observation }\end{array}$ \\
\hline Satureja obovata Lag. & té de moro, té moruno & $\mathrm{J}$ & Digestif & Ortuño, 2003 \\
\hline Satureja montana L. & $\begin{array}{l}\text { té, té blanco, té de flor blanca, té de } \\
\text { piedra, té montesino, té de roca }\end{array}$ & $\mathrm{Hu}$ & Digestif, carminative, antidiarrhoeic & Villar et al., 1987 \\
\hline Sideritis hirsuta $\mathrm{L}$. & té, té de la Mariola, té del páramo & $\mathrm{P}, \mathrm{V}$ & Digestif $^{b}$ & $\begin{array}{l}\text { Font Quer, 1962; Oria de Rueda et } \\
\text { al., } 1996\end{array}$ \\
\hline Sideritis hyssopifolia $\mathrm{L}$. & $\begin{array}{l}\text { té, té amarillo, té borriquero, te de } \\
\text { bosc, te de botja, te d'espiga, té de } \\
\text { Galba, té de glera, té de la peña, té de } \\
\text { lastra, te de matxo, te de muntanya, } \\
\text { té de monte, té de pastor, té de peña, } \\
\text { té de Picos de Europa, té de Picos, té } \\
\text { de piedra, té de puerto, té de roca, té } \\
\text { de tasca, té fino, te negre, té purgante, } \\
\text { té rastrero, té salvatge, té verdadero }\end{array}$ & $\mathrm{Ge}, \mathrm{Hu}, \mathrm{L}, \mathrm{O}, \mathrm{P}, \mathrm{S}, \mathrm{PVS}$ & $\begin{array}{l}\text { Digestif, to treat gastric ulcers, } \\
\text { antidiarrhoeic }\end{array}$ & $\begin{array}{l}\text { Villar et al., 1987; Barandiarán and } \\
\text { Manterola, 1990; Muntané, 1994; } \\
\text { Ferrández and Sanz, 1993; Agelet, } \\
\text { 1999; Agelet and Vallès, 2003; } \\
\text { Lastra, 2003; Pardo de Santayana, } \\
\text { 2003; San Miguel, } 2004\end{array}$ \\
\hline Sideritis romana $\mathrm{L}$. & té salvaje, té silvestre & Cs & $\begin{array}{l}\text { Digestif, carminative, to lower blood } \\
\text { pressure }\end{array}$ & Mulet, 1991 \\
\hline Teucrium polium $\mathrm{L}$. & té de piedra, te de roca & $\mathrm{J}$ & Digestif, aperitif, slimming & $\begin{array}{l}\text { Agelet, 1999; Fernández Ocaña, } \\
2000\end{array}$ \\
\hline Thymus leptophyllus Lange & té ratero & $\mathrm{Cu}$ & Digestif, anticatarrhal agent & Verde, 2003 \\
\hline Thymus mastichina (L.) L. & té de sierra, té esport & $\mathrm{J}$ & $\begin{array}{l}\text { Digestif, anticatarrhal agent, } \\
\text { analgesic }^{\mathrm{b}}\end{array}$ & $\begin{array}{l}\text { Fernández Ocaña, 2000; Ortuño, } \\
2003\end{array}$ \\
\hline
\end{tabular}


Thymus praecox Opiz

Thymus pulegioides $\mathrm{L}$.

Ziziphora hispanica $\mathrm{L}$.

PLUMBAGINACEAE

Armeria alpina Willd.

POACEAE

Polypogon monspeliensis (L.)

Desf.

ROSACEAE

Alchemilla alpina $\mathrm{L}$.

Potentilla caulescens $\mathrm{L}$.

(MA55201)

é morado, té moruno

té, té de la sierra, té de los moros, té

de sierra, té fino, té morado, té

moruno

té, té de espiguilla

té

té, té de roca

té de roca, té de señor, te de

té, té de bosc, té de Guara, té fino
S

Digestif, diuretic

Digestif, diuretic, anticatarrhal agent, antidiarrhoeic ${ }^{\mathrm{a}}$

Ab, Gr Digestif

$\mathrm{Hu}$

Digestif

Aperitif

Digestif

Digestif

Digestif
Pardo de Santayana, 2003

Villar et al., 1987;

González-Tejero, 1990; Lastra,

2003; Pardo de Santayana, 2003

González-Tejero, 1990

Villar et al., 1987

Fernández Ocaña, 2000

Font Quer, 1962

E. Blanco personal observation

Villar et al., 1987

Cruciata glabra (L.) Ehrend.

a Species used as digestifs in 1-5 areas where they are not called té.

b In 6-10 areas.

${ }^{c}$ In more than 10 areas. 
Tables 1 and 2 only include those species for which new data are available.

\section{Results}

According to Juanini (cited in Colmeiro, 1895), tea began to be used in Spain as a medicine at the end of the seventeenth century, the term té appearing in the Official Dictionary of the Spanish Language in its 1739 edition. The first report of a popular name derived from té is té de España for Chenopodium ambrosioides (Quer, 1762-1764; Palau, 1784-1788). In the last decades of the nineteenth century the term té was borrowed to denote autochthonous species such as Jasonia glutinosa, Chenopodium botrys, Lithospermum officinale, Veronica officinalis or allochthonous species such as Chenopodium ambrosioides (Colmeiro, 1885-1895). Other té-derived names that appear at this time in dictionaries or even in the botanical literature, such as té de Siberia (Siberian tea, Potentilla sp. pl.), té de Paraguay (Paraguayan tea, Ilex paraguariensis A. St.-Hil., Aquifoliaceae), or té del Caúcaso (Caucasus tea, Arctostaphyllos uva-ursi (L.) Spreng., Ericaceae), are loans or translated names from other European languages, that have not become popular (Colmeiro, 1871). It is supposed that during the nineteenth century the term té became more widely used in Spanish as a term for certain infusions with medicinal properties. This expansion continued during the twentieth century; the group of species popularly known as té has increased in size over the last hundred years from 5 to more than 70 species.

Table 1 shows the species now popularly known as té (ordered by family) and the regions where they are used as digestive infusions. It also includes other species used to improve the digestive process. Their medicinal uses and té-derived names are also included. Table 2 shows other plants known as té although at the moment we have insufficient information regarding their use as digestive infusions. According to Peris et al. (2001), many of the plants in Table 2 have stomachic properties (Marrubium vulgare, Meum athamanthicum, Nepeta cataria, Origanum vulgare, Tagetes minuta, Veronica officinalis).

The botanical families with the greatest number of té species recorded were the Lamiaceae (33 species) and Asteraceae (18 species). Other tés were found to belong to the Boraginaceae (Lithospermum officinale), Rubiaceae (Cruciata glabra), Geraniaceae (Erodium petraeum), Cistaceae (Helianthemum syriacum) and Clusiaceae (Hypericum perforatum).

The following paragraphs record the use of the nine most widely used species, in order of extent of use. All plants known as té and used as digestive infusions in more than three regions were taken as belonging to those species most widely used. Cultivated plants are mentioned after wild taxa. Finally, other interesting species, including those locally but frequently used, are also mentioned. References included in Table 1 have been omitted in the text for practical reasons.

\subsection{Jasonia glutinosa}

Popular names: té, té de Aragón, té de montaña, té de peña, té de piedra, té de risco, té de roca, árnica.

Perennial plant with woody roots and fragile stems, $15-30 \mathrm{~cm}$. Leaves lanceolate, up to $3 \mathrm{~cm}$, with glandular sticky hairs. Capitula numerous, with tubular yellow florets, ligules absent. Fruits c. $3 \mathrm{~mm}$, hairy. The species grows on calcareous rocks in eastern Spain, southern France and Morocco. It is exceptionally variable (Brullo, 1979).

It should be collected in July or August when the plant is flowering; the flowering aerial part is easily gathered by breaking the stems, leaving the base undamaged. It is usually prepared with water, but also with milk, and in Aragón sometimes with anisette (liquor flavoured with aniseed). Some people enjoy drinking it cold with ice. It is without doubt the most popular species and is considered a delicacy. Many restaurants serve it, and it is sold in local markets, in souvenir shops in tourist regions such as the Ciudad Encantada (Cuenca), in bars and herb shops. It has been marketed by companies such as Santiveri, Soria Natural and others (Arteche et al., 1994), and is available on the Web (e.g., Ecoaromuz; http://ecoaromuz.com/). New Jasonia glutinosa products are appearing and some restaurants now offer té de roca ice cream (e.g., La Prensa, Zaragoza; Fonda Farré, Sort, Lérida; El Doncel, Sigüenza, Guadalajara). In Spain, it is used in nearly all the regions where it grows (Fig. 2), but although its area of distribution includes Morocco, no mention of its use was found for that country.

A species described from Malta as Chiliadenus bocconei Brullo (but here recognised as Jasonia bocconei (Brullo) Pardo de Santayana \& Morales) was recorded as being very rarely used to treat diabetes (Pardo de Santayana and Morales, 2004). According to Bermejo et al. (1995), Jasonia glutinosa contains phenolic acids derived from caffeic acid, flavonoids and essential oils. These oils are rich in camphor, borneol and cis-nerolidol (Esteban, 1995) and also contain sesquiterpenic lactones (Mulet, 1991). Its stomachic, antispasmodic and carminative activities have been used to help digestive disorders, but it has also been prescribed to help with colds, as an antidepressive, as a vulnerary, and for whitening the teeth (Villaescusa et al., 2000; Peris et al., 2001; Benito et al., 2002; Muñoz, 2003; Romero et al., 2003). It is quite abundant, and despite intense collection, its natural populations are not endangered. It is easy to cultivate, and should be studied in depth for its phytotherapeutic interest.

The closely related species, Jasonia tuberosa-té de tierra (soil tea), differs in its ligulated flowers and tuberous roots. This species lives in damp places in the centre and northeast of the Iberian Peninsula. Both species are considered similar but usually one or the other is preferred. It is gathered and consumed in Madrid, Guadalajara, Segovia and Burgos and possibly elsewhere. Bermejo et al. (1995) indicate that it also contains flavonoids and essential oils. 
Table 2

Other species called té in Spain

\begin{tabular}{|c|c|c|c|c|}
\hline Scientific name & Vernacular name & Area of use & Popular use & Reference \\
\hline \multicolumn{5}{|l|}{ APIACEAE } \\
\hline Meum athamanticum Jacq. & té purgante & $\mathrm{Hu}$ & Diuretic, laxative & Villar et al., 1987 \\
\hline \multicolumn{5}{|l|}{ ASPLENIACEAE } \\
\hline Ceterach officinarum Willd. & té, té bravío & Co & $\begin{array}{l}\text { Anticatarrhal agent, headache } \\
\text { treatment, diuretic }\end{array}$ & $\begin{array}{l}\text { Font Quer, 1962; Molina } \\
\text { Mahedero, } 2001\end{array}$ \\
\hline \multicolumn{5}{|l|}{ ASTERACEAE } \\
\hline $\begin{array}{c}\text { Artemisia chamaemelifolia } \\
\text { Vill. (MA505844) }\end{array}$ & té moro & $\mathrm{Al}$ & Digestif? & $\begin{array}{l}\text { J. Herrero, personal } \\
\text { communication }\end{array}$ \\
\hline Bidens tripartita L. & té & Le? & Digestif? & Esgueva, 1999 \\
\hline Dittrichia viscosa (L.) Greuter & té hierba del hueso & CAT? & Unknown & Masclans, 1981 \\
\hline Inula conyza DC. & té purgante & $\mathrm{Hu}$ & Laxative, vulnerary & Villar et al., 1987 \\
\hline Tagetes minuta L. & té maloliente; te pudent & $\mathrm{Cs}$ & Vulnerary & Font Quer, 1962; Mulet, 1991 \\
\hline $\begin{array}{l}\text { BORAGINACEAE } \\
\text { Buglossoides arvensis (L.) } \\
\text { I.M. Johnst. }\end{array}$ & té, té de campo & $\mathrm{Gr}$ & Slimming & González-Tejero, 1990 \\
\hline \multicolumn{5}{|l|}{ CAMPANULACEAE } \\
\hline Jasione foliosa Cav. & té de roca & $\mathrm{Ca} ?$ & Unknown & Aparicio and Silvestre, 1987 \\
\hline Jasione montana L. & té de monte & $\mathrm{Ca} ?$ & Unknown & Aparicio and Silvestre, 1987 \\
\hline \multicolumn{5}{|l|}{ CHENOPODIACEAE } \\
\hline Chenopodium botrys L. & $\begin{array}{l}\text { té bodris, té de } \\
\text { Valladolid }\end{array}$ & Va? & Antihelminthic & Font Quer, 1962 \\
\hline \multicolumn{5}{|l|}{ CLUSIACEAE } \\
\hline Tuberaria guttata (L.) Fourr. & té de sierra & $\mathrm{J}$ & Stimulant & Guzmán Tirado, 1997 \\
\hline \multicolumn{5}{|l|}{ LAMIACEAE } \\
\hline Clinopodium vulgare L. & té & Le? & Unknown & Esgueva, 1999 \\
\hline Lycopus europaeus L. & té americano & Le? & Unknown & Esgueva, 1999 \\
\hline Marrubium vulgare L. & té bravo & Le? & Unknown & Esgueva, 1999 \\
\hline Nepeta cataria L. (1408RM) & té, té de río, té de vega & CR & Digestif? & R. Morales, personal observation \\
\hline Origanum vulgare L. & té de roig, té roig, té rojo & Cs & $\begin{array}{l}\text { Depurative, antirrheumatic, } \\
\text { anti-inflammatory }^{\mathrm{a}}\end{array}$ & Mulet, 1991 \\
\hline Sideritis montana $\mathrm{L}$ & té de campo & PVL? & Unknown & Figuerola et al., 1988 \\
\hline Sideritis pungens Benth. & té de aljézar & $\mathrm{P} ?$ & Unknown & Oria de Rueda et al., 1996 \\
\hline Teucrium webbianum Boiss. & té & $\mathrm{J}$ & To lower blood pressure & Ortuño, 2003 \\
\hline \multicolumn{5}{|l|}{ LYTHRACEAE } \\
\hline Lythrum salicaria L. & té de brazal & $\mathrm{Hu}$ & To lower blood pressure & Ferrández and Sanz, 1993 \\
\hline \multicolumn{5}{|l|}{ RUBIACEAE } \\
\hline Galium verum L. & té & $\mathrm{Hu}$ & Vulnerary, Digestif? & Villar et al., 2001 \\
\hline \multicolumn{5}{|l|}{ SCROPHULARIACEAE } \\
\hline Veronica officinalis L. & $\begin{array}{l}\text { té de España, té de } \\
\text { Europa, té de montaña, } \\
\text { té de ribera, té del país }\end{array}$ & Unknown & To treat eczema & Font Quer, 1962 \\
\hline
\end{tabular}

${ }^{a}$ Species used as digestif in 10 areas where it is not called té.

\subsection{Sideritis hyssopifolia}

Popular names: té, té amarillo, té de lastra, té de monte, té de Picos de Europa, té de puerto, té de roca.

Perennial plant with a woody base, up to $40 \mathrm{~cm}$; leaves lanceolate, $1-4 \mathrm{~cm}$, entire, shallowly toothed or crenate (its specific name refers to the similarity between its leaves and those of Hyssopus officinalis L., Lamiaceae). Inflorescence densely spiciform, with dentate bracts and yellow flowers. It is extremely variable and has often been divided into a number of forms, varieties and subspecies. It lives in rocky places and mountain pastures, proliferating from the Pyrenees to the interior of Galicia. It also grows in the French Alps and in some places in peninsular Italy and Sicily.

An infusion of the inflorescence is taken as a stomachic after difficult digestions and as a treatment for stomach pain. It is also consumed at breakfast, in bars and restaurants as a social beverage (like tea or coffee), or at home after family meals. It is very common to prepare herbal liqueur digestifs by macerating the inflorescences in liquor. This plant is popular in the Cantabrian Mountains and the Pyrenees (Fig. 2). It is widely consumed in Cantabria, especially in the Pi- 


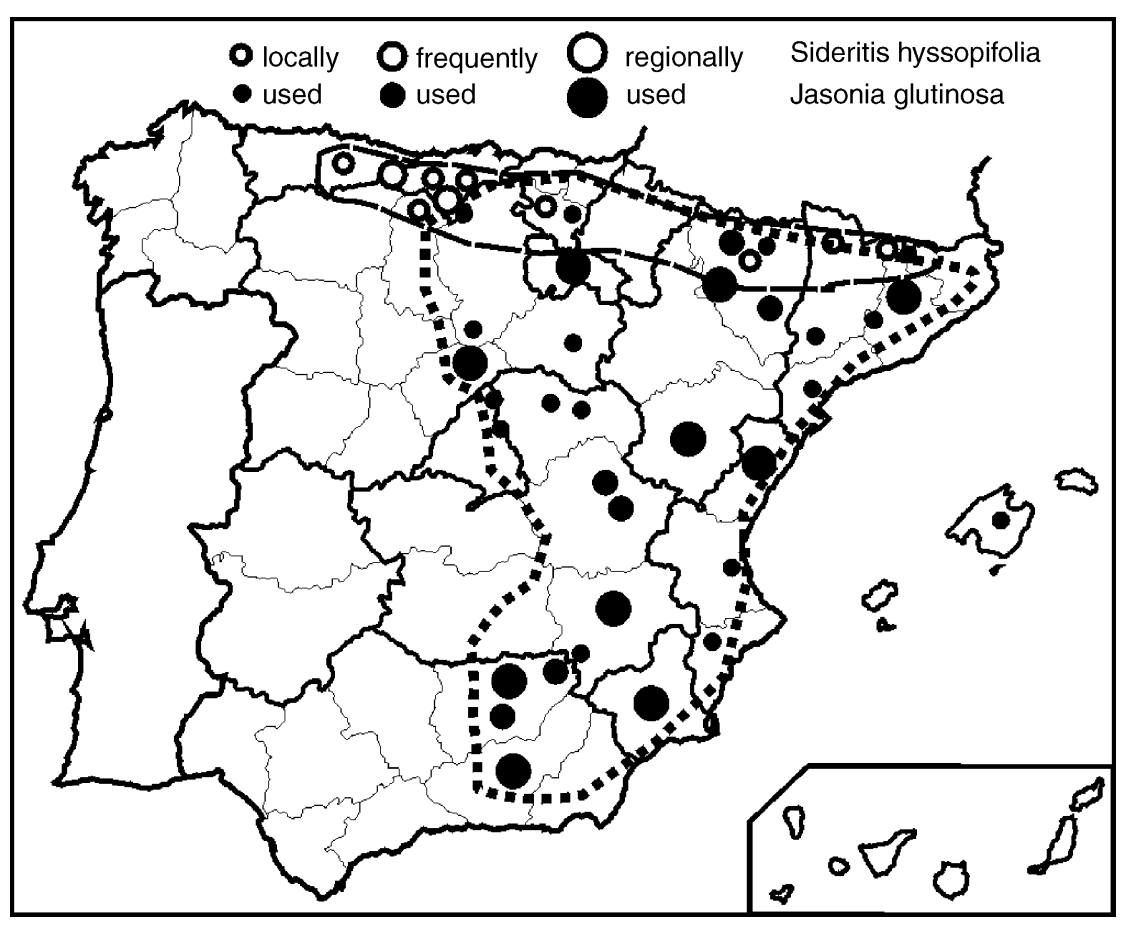

Fig. 2. Area of use of Sideritis hyssopifolia and Jasonia glutinosa.

cos de Europa mountain range and nearby areas, where it is commonly gathered and considered a mark of local gastronomic identity. Rural tourism is quite important in this region, and té del puerto is offered in bars, sometimes mixed with cognac. It is sold in the main town of Potes at about 3 euros per bunch (about $100 \mathrm{~g}$ ). The species is also used to aromatise homemade and commercial herb liqueurs, and it is even available on the Web. Its French name is the de montagne (mountain tea; Saule, 1991) and it is consumed and marketed in the French Alps (http://www.bergtee.de/about.htm). It is a good remedy for problems of digestion and is very aromatic. Rodríguez Lion (1997) indicates that this species contains phenolic acids (chlorogenic acid), flavonoids (hypolaetine, isoscutellarein) and essential oils with a high content in hydroxycinnamic derivatives. Pharmacological essays have shown that its flavonoids are responsible for its digestive properties (Adzet et al., 1987; Rodríguez Lyon et al., 2000).

The species suffers intense collection (including for commercial purposes) and studies should be performed to see whether this is a sustainable activity. We only know of some private attempts to grow the species in gardens; it would be very interesting to try to cultivate it.

Some species that usually go by the name of rabo de gato (cat tail) (Sideritis romana, Sideritis montana, Sideritis hirsuta) may also be called té and are consumed as digestive infusions in different parts of Spain. Sideritis hirsuta is used in many places such as Castellón, Jaén or Gerona (Mulet, 1991; Mesa, 1996; Parada et al., 2002) to improve the digestion, although it is not very common to call it té. Some of these species have anti-inflammatory properties due to their high flavonoid content (Peris et al., 2001).

\subsection{Acinos alpinus}

Popular names: té, té de campo, té de roca, té de Sierra Nevada, té de tierra, té fino, poleo montesino.

Perennial plant up to $30 \mathrm{~cm}$, with reptant and erect stems. Leaves ovate with conspicuous lateral veins. Flowers solitary in axils of leaves; calyx thickened at the base, with three upper longer teeth and two more that are lower down, shorter and hairy. Corolla elongate, violet to purple, longer than the calyx. It lives in cold places, mountains and moorlands all over Spain and is found in other parts of Europe, Turkey and northeast Africa.

An infusion of the flowering aerial part is consumed to aid digestion. Some people like to mix it with milk. In Spain it is consumed as a digestive infusion only in the southeastern provinces and in Guadalajara (Fig. 3). It is very popular in the Sierra de Mágina and the Sierra de Cazorla (Jaén) and the Sierra Nevada (Granada). It is locally marketed in the latter region. This té has a very pleasant aroma since it contains pulegone, as well as $\alpha$-pinene, menthone and limonene. It has antispasmodic, antiseptic and anti-inflammatory properties (Velasco-Negueruela et al., 1993; Esteban, 1995; Kaya et al., 1999).

It is relatively common and seems not to have any problems of conservation. The very closely related species Acinos arvensis receives similar names and is similarly used in the Sierra de Alcaráz and Sierra de Segura (Albacete). 


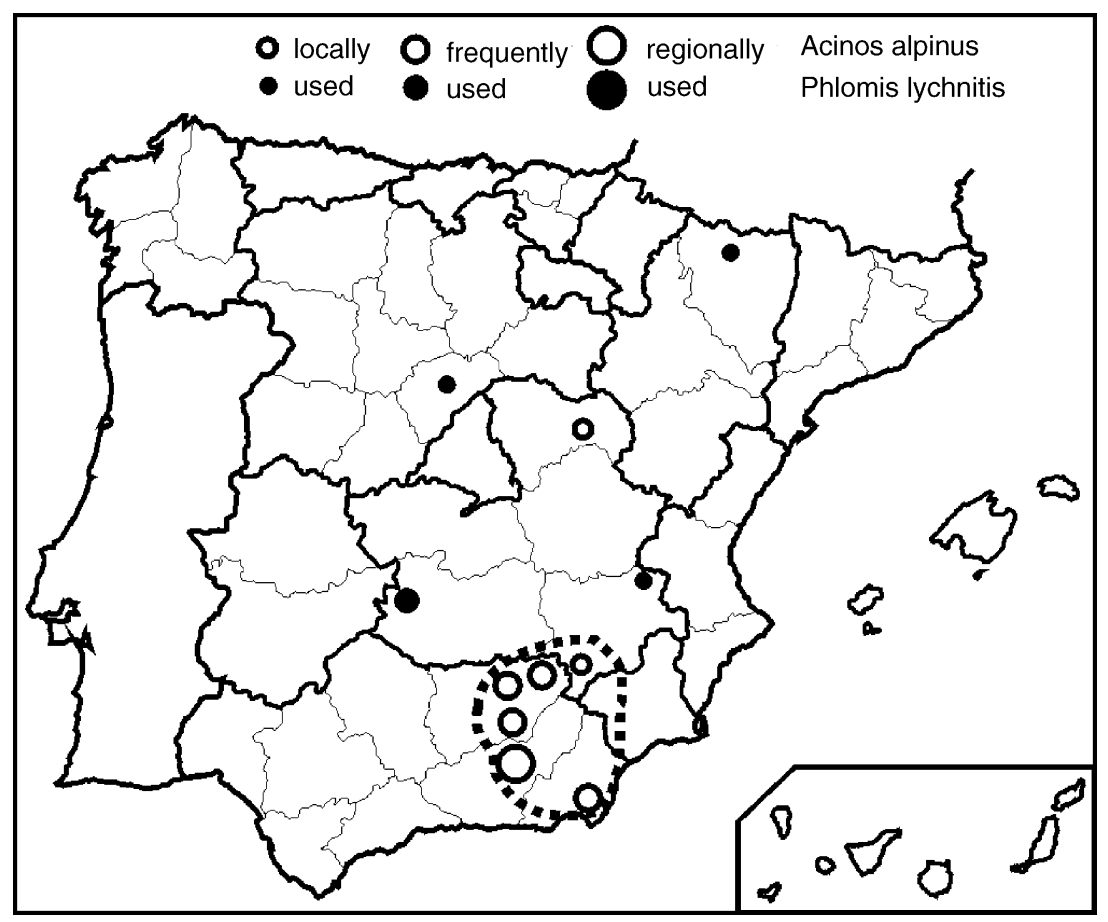

Fig. 3. Area where Phlomis lychnitis and Acinos alpinus are called té and used as digestive infusions.

\subsection{Phlomis lychnitis}

Popular names: té, té de monte, té de pastor, té moruno, candilera, matagallo, torcida.

Perennial hairy shrub up to $50 \mathrm{~cm}$ with linear-lanceolate leaves. Bracts of inflorescences ovate or rhombic, cuspidate. Flowers yellow, arranged in dense verticillasters, with the superior corolla lobule concave. It is relatively common in scrub lands. It prefers the basic substrates of the east and centre of the Iberian Peninsula and the south of France.

The species is used as a stomachic especially in the Campo de Calatrava (La Mancha), where it is very popular; herb gatherers sell it in local markets and prescribe it for stomachache. It is also used for the same purpose in Albacete, Segovia and Huesca (Fig. 3), in this case due to the popular wisdom of immigrants from Extremadura, Córdoba and Jaén (although in these last two regions it is not called té; Fernández Ocaña, 2000; Molina Mahedero, 2001). It is poor in volatile substances but its essential oil is rich in $\alpha$-pinene and caryophyllene (Esteban, 1995). It has also been used to treat diarrhoea, haemorrhoids and fever (Peris et al., 2001).

\subsection{Mentha pulegium}

Popular names: té, té de charca, té de menta, té de prao, té del campo, té poleo, menta, poleo.

Perennial herb, $20-40 \mathrm{~cm}$, with more or less hairy elliptical leaves. Inflorescences in semispherical verticillasters, separated by internodes, with little and regular pink flowers with exerted stamens. It grows on prairies and periodically flooded areas across the Iberian Peninsula. It is found all over
Europe as well as in the north of Africa and in Asia, and grows as a feral species in parts of America.

The whole aerial plant in flower is used to prepare the infusion, which is very aromatic. Although, it is one of the most popular digestive infusions in Spain (e.g., Mesa, 1996; Pardo de Santayana, 2003), it is only called té in Albacete, Cuenca and Granada (Fig. 4). It usually receives the name poleo (from the Latin pulex [flea] because its smell is said to drives off fleas). It is very commonly used to treat diarrhoea and many other illnesses, and sometimes for flavouring food and preparing liqueurs (Fernández Ocaña, 2000; Parada et al., 2002). Its essential oil mainly contains pulegone, piperitenone, isomenthone and menthone (Esteban, 1995). The infusion is said to have antispasmodic, antiseptic and sedative properties (Peris et al., 2001).

Other mints called té include Mentha x piperita, Mentha longifolia and Mentha aquatica. All mints can be used as stomachic infusions, but Mentha pulegium, Mentha x piperita and Mentha spicata L. are particularly popular (e.g., Guzmán Tirado, 1997; Bonet, 2001). Mentha arvensis is only known to be used in Madrid and has a very different aroma.

\subsection{Thymus pulegioides}

Popular names: Té, té de sierra, té morado, té moruno, serpol.

Perennial plant, $20-40 \mathrm{~cm}$, with long rectangular stems, hairy only in the angles. Leaves elliptic, glabrous, 3-9 $\mathrm{mm}$. Inflorescence in verticillasters; flowers with hairy calyx and purple corolla. Grows in wet but not flooded places, e.g., the edges of pastures and roads. In Spain, it lives mainly in the 


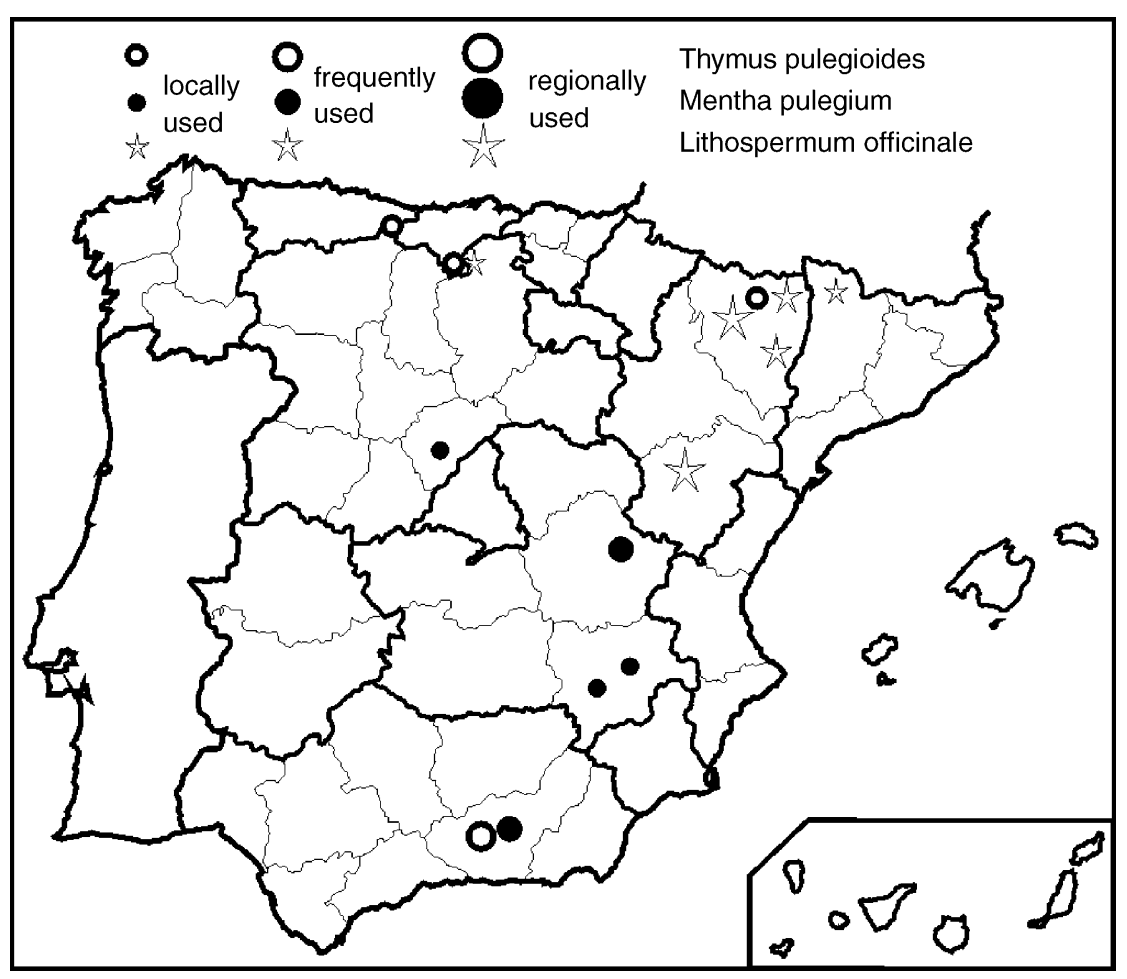

Fig. 4. Area where Mentha pulegium, Thymus pulegioides and Lithospermum officinale are called té and used as digestive infusions.

northern half of the country; in the south it is found only in the Sierra Nevada. It grows throughout the rest of Europe.

The entire flowering aerial part of the plant is gathered and used in infusions. In the North of Spain, Granada and Almería it is called té and is mainly used as a digestif (Fig. 4) but also as an anti-inflammatory, a diuretic, an antidiarrhoeic, and as a sedative. Its essential oil contains thymol, carvacrol, geraniol and p-cymene (Esteban, 1995).

Other thymes called té are Thymus mastichina, Thymus praecox and Thymus leptophyllus. All these species have been used for treating digestive disorders, as have other species such as Thymus baeticus Boiss. ex Lacaita, Thymus serpylloides Bory and Thymus longiflorus Boiss. in Granada (González-Tejero, 1990), Thymus hyemalis Lange in Murcia and Almería (Martínez Lirola et al., 1997; Rabal, 2000), or Thymus orospedanus Villar in Jaén (Guzmán Tirado, 1997). Thymus mastichina, usually called tomillo blanco (white thyme) or mejorana (marjoram), is quite a common species that only grows in the Iberian Peninsula. It is very rich in essential oils such as thymol and eucalyptol and is widely used to treat respiratory and digestive disorders. It is also commonly employed as a preservative and flavouring agent for olives and beef dishes (Peris et al., 2001; Tardío et al., 2002).

\subsection{Lithospermum officinale}

Popular names: té, té de acequia, té de Benasque, té de huerta, té de perla, herba pedrera, mijo del sol.

Rhizomatous perennial herb, $30-80 \mathrm{~cm}$, with lanceolate leaves up to $10 \mathrm{~cm}$. Flowers yellowish to white, $5 \mathrm{~cm}$ long.
Fruits ovoid, grey to white, pearly, 3-4 mm. It grows in hedges, gardens and streamsides but is not very common. It lives in the northern half of Spain and across most of Europe. It is common in gardens in the south of Cantabria and was once common in southern and northern Aragón (Loscos and Pardo, 1867). It is unlikely that it was ever widely cultivated.

Its fruiting aerial part is used in an infusion to improve digestion, especially in northern Spain (Aragón, Lérida and Cantabria) (Fig. 4). According to the Doctrine of the Signatures, it was used to treat kidney stones (since its seeds are similar in appearance to pearls). Many people still believe it has litholytic properties. It is commonly taken as a diuretic and has also been employed as an anticatarrhal and anti-inflammatory medicine (Bonet, 2001). Due to its content in pyrrolizidine alkaloids (Dharmananda, 2001) it should not be consumed continuously since it can be hepatotoxic and even carcinogenic. Since it is intensely used, its properties and effects should be better studied.

\subsection{Chenopodium ambrosioides}

Popular names: té, té burrero, té de Europa, té de Méjico, té de Nueva España, té hormiguero, pazote.

Annual or biannual herb, up to $1 \mathrm{~m}$, with conduplicatelanceolate leaves. Inconspicuous green flowers arranged in leafy spikelets. The species is American in origin and now lives wild almost everywhere Spain as a ruderal, nitrophilic plant.

The plant has a characteristic aroma. Its dried leaves are prepared as an infusion and give an intense yellow colour 


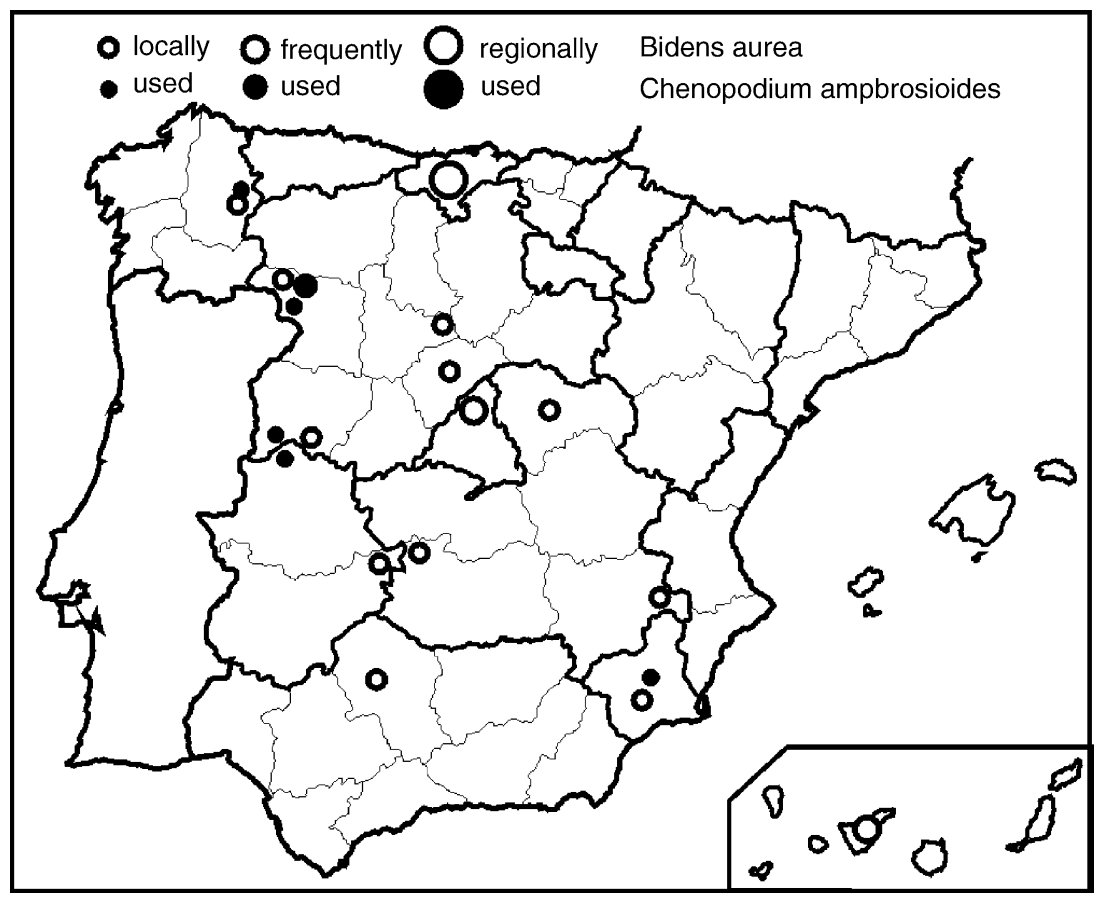

Fig. 5. Area where Bidens aurea and Chenopodium ambrosioides are called té and used as digestive infusions.

to the water. This has a pleasant, mild flavour if it is not too concentrated. Its use in the treatment of digestive disorders is quite old (Quer, 1762-1764) and extended, especially in western Spain (Galicia, Extremadura, western Castilla y León) (Fig. 5) and northeastern Portugal (R. Morales and M. Pardo de Santayana, personal observations). It is also used as an antihelminthic and anticatarrhal agent due to its ascaridol content (Font Quer, 1962; Bonet, 2001).

A closely related species is Chenopodium botrys, known as té de Valladolid (Valladolid tea); this has been used to treat coughs (Font Quer, 1962) and probably for digestive disorders.

\subsection{Bidens aurea}

Popular names: té, té americano, té de huerta, té de Méjico, té de Canarias, té moruno.

Stoloniferous, perennial rhizomatous herb, up to $70 \mathrm{~cm}$, with broadly lanceolate, serrate leaves. Capitula with six ligulated white-yellowish flowers, dentate at the apex. It flowers in autumn, but in cold climates it does not flower. It is also an American species; the date of its arrival is unknown but it probably came via the Canary Islands, and has since become an invasive species in gardens and riversides in the proximity of human settlements. It grows feral over nearly all of the Iberian Peninsula and southern Europe.

Its dried leaves are consumed as a tisane or infusion. Its flavour is mild and pleasant when the infusion is sweetened. In some villages of the Montes de Toledo the leaves are roasted before preparing the infusion. It is usually gathered in autumn, especially on the first of November (All Saints Day).
People also use its flowers in the villages of the Montes region (Ciudad Real). It is used all trough Spain in many regions such as Murcia, Galicia, Extremadura, Zamora, Salamanca, Valladolid, Madrid, Segovia and Cantabria (Fig. 5). The chemical composition of Bidens aurea is not well known, although the flavonoid fraction has healing effects on gastric ulcers in rats (Alarcón et al., 1997). Many species of the genus contain tannins and are astringent.

Other species such as Bidens leucantha are used in a similar manner in Latin America. Bidens tripartita contains the polyalkyne phenylheptatriyne (Bruneton, 1999).

\subsection{Other widely used plants}

Calamintha nepeta is rather popular in the south, especially in Granada. In Castellón (Mulet, 1991), Jaén (Fernández Ocaña, 2000) and Badajoz (Blanco and Cuadrado, 2000), it is known as poleo, menta or añota, and it is consumed as an aid to digestion. Its essential oils are rich in terpenic monoxides, monoterpenones and monoterpenols. It is also used to treat fevers and respiratory and digestive disorders (Peris et al., 2001).

Micromeria fruticosa is commonly used in some areas of eastern and northern Spain (Castellón, Cuenca, Huesca) as a digestif, a laxative, to lower the blood pressure, as a vulnerary and as a social beverage, although it is only called té in Castellón and Cuenca. Its essential oil is rich in monoterpenones (pulegone) (Villar et al., 1987; Mulet, 1991; Peris et al., 2001; Verde, 2003).

Melissa officinalis, Thymus mastichina, Helichrysum stoechas, Hypericum perforatum, Lavandula stoechas, 
Satureja montana or Achillea millefolium are commonly consumed as digestive infusions but are called té only in a few regions. Melissa officinalis is commonly cultivated in gardens and grows feral in the surroundings of inhabited places. Its digestive and carminative effects are owed to its essential oils, which are rich in citral, geraniol and linalol. It also has antispasmodic properties and is used to treat gastric/nervous disorders. It is the main component of a number of medicinal digestive beverages such as the Spanish agua del Carmen (Carmen water) or the German Klosterfrau-Melissengeist (nun balm medicinal spirit) (Furlenmeier, 1984). Helichrysum stoechas is rich in flavonoids, sesquiterpenes, monoterpenols, terpenic esters and ketones. It has antispasmodic, antiseptic and cough-soothing properties and is popularly used for digestive and respiratory disorders. It is common to call it manzanilla; it is only called té to the north of Burgos and in the Basque Country. Achillea millefolium is rich in azulene, $\alpha$-pinene, caryophyllene, flavonoids, sesquiterpenic lactoses and tannins. It has anti-inflammatory, antispasmodic, cholagogic, emmenagogic and wound-healing properties and is indicated for stomach, nervous, menstrual and other disorders (Font Quer, 1962; Furlenmeier, 1984; Peris et al., 2001).

Origanum vulgare is called té rojo (red tea) only in Castellón, where it is not employed as a stomachic. However, in other areas where it is not known as té, it is used as a stomachic (Fernández Ocaña, 2000; Rabal, 2000; San Miguel, 2004) as well as a treatment for coughs (Verde et al., 1998; Pardo de Santayana, 2003). Its essential oils are rich in monoterpenes, phenolic acids (such as caffeic acid) and flavonoids (Peris et al., 2001).

Many other species are consumed as digestive infusions but are not called té. Among the most common are Matricaria recutita L., Santolina chamaecyparissus L., Chamaemelum nobile (L.) All., Foeniculum vulgare Mill., Thymus vulgaris L., Rosmarinus officinalis L., Lavandula latifolia Medik., Anthemis arvensis L. and Salvia lavandulifolia (Vahl).

\subsection{Other species with a more restrictive area of use}

Cruciata glabra is consumed exclusively in the Alto Aragón where it is greatly appreciated. Its name, té de Guara, indicates the place where it is gathered. In the interior of the Tarragona province, some people like to consume Potentilla caulescens and give it the expressive name of té del señor (Lord's tea). Erodium petraeum is used in Castellón and Mágina (Jaén)—in the latter it is known as manzanilla de Mágina (Mesa, 1996) — as a carminative, to lower the blood pressure and as a calming agent. People from the Sierra de Gredos (Ávila and Cáceres) use Solidago virgaurea for digestive purposes, although the phytotherapeutic literature more commonly records its diuretic properties. Nowadays only a few people gather it. It contains saponines, bitter compounds, tannins and essential oils (Furlenmeier, 1984). Helianthemum cinereum is used as an aid to digestion in Murcia (Obón and Rivera, 1981) and Albacete, but is called té only in the latter region. It is highly appreciated as anti-inflammatory and vulnerary.

\section{Discussion}

After tea was introduced into Spain, the term té acquired a broader significance, eventually becoming a generic word for many other plants and their infusions. These can be divided into two groups according to their extension of use: those that are widely used such as Jasonia glutinosa, Bidens aurea and Sideritis hyssopifolia (see Figs. 2 and 5) and those that are consumed more locally (though they may grow more widely), such as Cruciata glabra, Inula salicina, Conyza canadensis, Erigeron acer and Potentilla caulescens (Fig. 6).

The extension of the use of these plants and the multiplicity of vernacular names derived from té indicate their popularity. The most important are Jasonia glutinosa, Sideritis hyssopifolia, Lithospermum officinale, Acinos alpinus and Chenopodium ambrosioides. The latter was denominated at the end of the nineteenth century (Colmeiro, 1885-1895) with more than 10 té-derived names, and as it was stated before, it is the oldest species known that loaned the name té from Camellia sinensis.

Though most of these tés grow naturally in the Iberian Peninsula, some are American species that have established themselves in the wild in many parts of Spain. Such is the case of té de Méjico or té de Argentina (Mexican tea or Argentinean tea; Bidens aurea, Chenopodium ambrosioides). These species were probably brought for cultivation in Spain but became wild and are now found scattered around gardens and human settlements. Exactly how these American plants were introduced and how their use spread has not been documented. Nonetheless, one of the popular names of Bidens aurea is té de Canarias (Canary Island tea), which might indicate that this taxon was introduced via the Canary Islands, where its use is very common (Pérez de Paz and Medina, 1988). One of its Portuguese names chá-espanhol, probably indicates that its use was known via Spain.

Popular history has been poorly attended to by historians, and there are few sources that study the everyday lives of common people. The lack of information makes it difficult to state when these species began to be popular. The most important books from the sixteenth and seventeenth century that speak of Spanish plants and their uses (Laguna, 1555; l'Ecluse, 1576; Cienfuegos, c. 1620; Quer, 1762-1764) do not mention very popular species such as Jasonia glutinosa and Sideritis hyssopifolia. It is impossible to determine whether this means they were not popularly used, although it is strange that Cienfuegos should fail to mention them if this were not the case.

The adoption of names derived from té is no older than some 300 years, but many of the taxa recorded here may have been used as digestive beverages long before this. Quer (1762-1764), Palau (1784-1788) and Cavanilles (1802) mention that people in Spain referred improperly to Chenopodium 


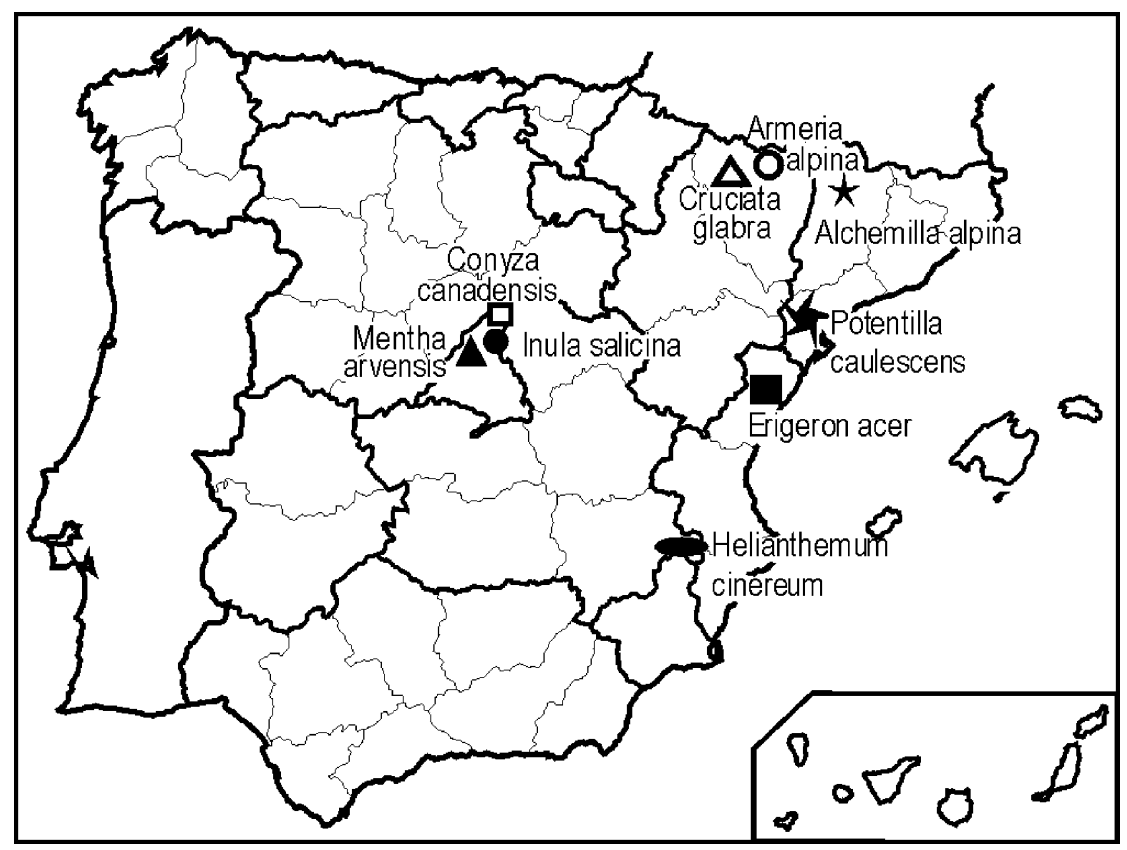

Fig. 6. Area of use of some species called té that are only locally used as digestive infusions.

ambrosioides with the voice té. They also pointed out that it was used against digestive disorders. Loscos and Pardo (1867) indicate that Jasonia glutinosa was very popular in Aragón, where it was known as té de Aragón. Since it was so popular even then, it is likely that is was used in the hundred years prior to this date. Gadow (1897), an English traveller who journeyed through the north of Spain during the 1880s, recorded this species as being called té de monte in the Picos de Europa (Cantabria), and that people used it for respiratory disorders. It is no longer used in the area, and only few people know of its medicinal properties (Lastra, 2003). Other vernacular Spanish names of the nineteenth century, such as planta del confitero (confectioner's plant) or hierba del hueso (bone herb) do not indicate that Jasonia glutinosa was used for its digestive properties.

Loscos and Pardo (1867) did not mention the use of Sideritis hyssopifolia in Aragón, and it is likely, therefore, that this species was not used there. Over a century later Villar et al. (1987) compiled several names for Sideritis hyssopifolia in this region, all derived from té. One of them, té borriquero (donkey tea) probably indicates that people preferred other tés such as that made with Jasonia glutinosa. Gadow did not mention the use of Sideritis hyssopifolia in the Picos de Europa, although he did record the use of Pinguicula grandiflora Lam. (Lentibulariaceae), Jasonia glutinosa and other popular medicinal species. If the available data can be trusted, and Sideritis hyssopifolia was not used in that region during the second half of the nineteenth century, it might have entered into use as a substitute for Jasonia glutinosa. Every region has preferred plants for each given illness or use, but if they are difficult to collect or disappear, others may take their place.
The main way to prepare healing plants in current popular Iberian medicine is as an infusion (e.g., Bonet et al., 1999; Pardo de Santayana, 2003). However, this was not so common in the past. The classics of Spanish literature, such as La Celestina written in 1499 by Fernando de Rojas, or El Quijote written by Cervantes in 1605, provide much information about popular medicine (Ceballos, 1965; MartínAragón, 1998) but very little is said about infusions. Cervantes disdained of infusions so strongly that he referred to them as "groseros bebedizos" or foul brews (poem 29; Cervantes, 1941). Balsams, syrups and other modes of preparations were preferred. Similar conclusions can be obtained from the notes of Laguna's translation of Dioscorides (1555) (Laguna was the Spanish physician to Pope Julius III).

Arteche et al. (1994) indicate that the phytochemistry and pharmacology of many of these traditionally used plants has been little studied. Only those of very popular species such as Jasonia glutinosa are relatively well known. People have usually considered tés as harmless, and certainly most taxa do not contain alkaloids and are neither excitant nor stimulant. However, Lithospermum officinale contains toxic substances that render its frequent use dangerous.

Many of the plants called té that are used as digestive remedies are known to have active ingredients that influence the efficiency of the digestive process. These are aromatic plants rich in: (A) essential oils containing carminative agents such as linalol, citral, geraniol (Melissa officinalis), camphor, borneol (Jasonia glutinosa, Mentha spicata); cholagogues and choleretics such as thymol, carvacrol (Lavandula stoechas, Satureja montana, Satureja obovata, Origanum vulvare, Thymus pulegioides) and ascaridol (Chenopodium ambrosioides); antispasmodics such as menthone and pule- 
gone (Calamintha nepeta, Mentha pulegium, Micromeria fruticosa); antiseptics such as eucalyptol (Thymus mastichina), $\alpha$-pinene (Phlomis lychnitis), limonene (Acinos alpinus), (B) sesquiterpenic lactones: eupeptics such as achillicin (Achillea millefolium), (C) flavonoids: anti-inflammatory agents ( $\mathrm{He}$ lichrysum stoechas, Hypericum perforatum, Sideritis hirsuta, Sideritis hyssopifolia, Sideritis romana), (D) organic acids: antispasmodics rich in phenolic acids such as caffeic acid (Jasonia glutinosa, Melissa officinalis, Nepeta cataria), (E) mucilage (Solidago virgaurea).

\subsection{Customs and habits of gathering and consumption}

Eating and drinking are social activities in most cultures, including those of the Mediterranean, that reflect status, friendship or kinship. Digestive infusions are 'social foods' that are not specifically ingested for their nutritional value. They are drunk either for the pleasure of their taste, while enjoying conversation after a familiar or social meal, or for health reasons. They may be drunk in bars and restaurants and are commonly offered to visitors to facilitate social relations. They are also used for their medicinal properties. The preferred moment to drink them is in the afternoon, but many people take them at breakfast or before going to bed. This kind of beverage can be considered a food medicine. The general interest in food medicine species has been highlighted by many authors (Etkin, 1996; Pieroni, 2000; Bonet and Vallès, 2002).

Popular tés are mostly used as digestive infusions or to relieve digestive system pain, but they may also have laxative, antidiarrhoeic, sedative and anti-hypertension functions, and are popularly used to treat general malaise.

Wild tés such as Sideritis hyssopifolia, Jasonia glutinosa, Acinos alpinus, Phlomis lychnitis, Thymus mastichina are gathered or bought to herb gatherers at weekly local markets. In big towns and cities one can also buy packed and labelled Jasonia glutinosa from herb shops. The latter and Sideritis hyssopifolia are available on the Web.

Except for some protected species, there are few restrictions on collection. Indeed, Andalusia and the Valencia region are the only Spanish political units that have regulated the gathering of wild medicinal plants, including some tés (Jasonia glutinosa, Micromeria fruticosa, Acinos alpinus, Mentha pulegium, Helichrysum stoechas, Helichrysum italicum, and all species of Thymus, Sideritis and Teucrium). The report by Lange (1998) on European medicinal plants ordered by the World Wildlife Fund (WWF) and the International Union for the Conservation of Nature (UICN) pointed out the possible dangers of the boom in herbal medicine, and indicate that the collection of some tés such as species of the genus Sideritis, Thymus and Origanum should be controlled. This is particularly important for taxa that are marketed. Fortunately, most of the plants mentioned in the present paper are only harvested for self consumption.

Most tés are consumed after drying, but some such as Jasonia glutinosa, can be prepared fresh. Bidens aurea is even roasted before preparing its infusion. The method of use is always an infusion or a 'boiled brew' (boiling the plant tissues for a few minutes) made with water, and sometimes mixed with milk (e.g., for infusions of like Camellia sinensis). Not many people distinguish infusions and boiled brews and use the term infusión to describe both. The appropriate dose is one or two teaspoons of dried plant material for each cup of water. Some tés are used to aromatise liqueurs. New ways of consuming them are now appearing, such as cold infusions or ice creams.

\subsection{Popular nomenclature}

Folk nomenclature can be very rich, and people often use creative, metaphorical names for biological entities. The majority of the names derived from té refer to the habitat where each species grows, e.g., té de sierra (high country tea), de puerto (mountain pass tea), de montaña (mountain tea), montés (scrubland or wild country tea), de campo (country tea), de barranco (gorge tea), de bosque (forest tea), de peña (rocky peak tea), de risco (crag tea), de roca (rock tea), de lastra (limestone tea), de río (river tea), de vega (valley tea) and de prado (meadow tea). These names do not apply solely to a single species, e.g., many of the tés that grow in rocky places are called té de peña, risco or roca (Potentilla caulescens, Satureja montana, Paronychia argentea, Acinos alpinus, Jasonia glutinosa, Sideritis glutinosa). Others that grow in wet places such as Mentha aquatica, Mentha arvensis, Nepeta cataria go by the common names of té de río or vega.

Other names can indicate a region of origin, such as té castellano (Castilian tea), chino (Chinese tea), americano (American tea), de Picos de Europa, de Peñagolosa, de Aragón, de Guara, de Gredos, de Granada, de Méjico, de Nueva España, etc. This last name has been simplified to té de España (Spanish tea rather than New Spain tea), but in fact it refers to the Mexican species.

Some names allude to the morphology of a certain part of the plant (flowers, seeds or inflorescence), e.g., té amarillo (yellow tea, the plant has yellow flowers), té de perla (pearl tea, which has pearly fruits), and té de espiguillas (spikelet tea, its inflorescences are spikelets). Some names such as té de burro (donkey tea) are pejorative (in this case for Jasonia tuberosa), whereas better tés, e.g., té de roca (Jasonia glutinosa), receive no such epithet. Other significant names such as té borde (rude tea), té salvaje (wild tea), té bravio (wildman's tea) differentiate them from the more highly appreciated cultivated species such as té de huerta (garden tea). Names such as té fino (refined tea) emphasize the esteem in which the species is held (the term refers to Lithospermum officinale, Acinos alpinus, Sideritis hyssopifolia, Thymus pulegioides and Cruciata glabra).

Other names allude to healing properties, e.g., té purgante (purging tea, Achillea millefolium, Inula conyza, Meum athamanticum) or té de tila (lime tree tea, Hypericum perforatum) (tila in Spanish has always referred to calming agents). 


\section{Conclusions}

The nomenclatural richness and range of uses for the approximately 70 species of plant known as té in Spain indicates the deep biocultural heritage surrounding these herbs. The term té was originally borrowed from that used to describe Camellia sinensis and then extended to many other plants during the second half of the nineteenth century and the twentieth century. The name té first appeared in the Official Dictionary of the Spanish Language at the beginning of the eighteenth century, and at the end of this century it was yet used to call species different from Camellia sinensis such as Chenopodium ambroisoides (Quer, 1762-1764).

The habit of drinking tea probably contributed to the popularisation of drinking other infusions for medicinal purposes and for the pleasure of their taste. Water infusions and boiled brews were not as common in the past as they are now, even though these are the easiest ways of preparing medicinal plants. People used to drink liqueurs, wine, milk or water; drinking infusions was apparently considered very strange. Although most European ethnobotanical traditions are being abandoned (Pardo de Santayana and Gómez Pellón, 2003), the use of many tés in Spain has increased in recent decades.

Almost all the species called té possess active ingredients with pharmacological benefits for the digestive system. Among these species are the greatly esteemed Jasonia glutinosa, Acinos alpinus, Sideritis hyssopifolia, Mentha pulegium and Bidens aurea which scored very high informant consensus in the regions where they are used (see González-Tejero, 1990; Mulet, 1991; San Miguel, 2004). The flavour of their infusions means these are also drunk as social beverages. Some species are so popular that they are considered a mark of local and regional gastronomic character and are an important facet of natural and cultural heritage. The term té also covers other less well known species such as Erodium petraeum, Cruciata glabra and Inula salicina, which are commonly consumed in more local areas. Further ethnopharmacological assessment and phytochemical studies of these tés are called for.

\section{Acknowledgements}

This study was supported by two grants from the Сотиnidad Autónoma de Madrid plus a Ph.D. fellowship awarded by the Spanish Ministry of Science and Education. We thank our informants for kindly sharing their knowledge with us and J. Tardío, A. Verde, J.P. Dugène, T. Tabone, A. Rosell, A. Agelet and J. Vallès for helping us find some of the information included in this paper. We are grateful to M.J. Macía, M.A. García, A. Burton and M. Heinrich for their input.

\section{References}

Adzet, T., Cañigueral, S., Ibáñez, C., Monasterio, I., Vila, R., 1987. Phytochemical investigation of Sideritis hyssopifolia var. pyrenaica. Pharmaceutisch Weekblad-Scientific Edition 9, 227.
Agelet, A., 1999. Estudis d'tnobotanica farmacèutica al Pallars, Ph.D. Thesis, Facultat de Farmàcia, Universitat de Barcelona, Barcelona.

Agelet, A., Valles, J., 2003. Studies on pharmaceutical ethnobotany in the region of Pallars (Pyrenees, Catalonia, Iberian Peninsula). Part II. New or very rare uses of previously known medicinal plants. Journal of Ethnopharmacology 84, 211-227.

Alarcón, C., La Casa, C., Motilva, V., López, A., Martín, M.J., 1997. Ulcer-protecting effects of a flavonoid fraction from Bidens aurea. Role of endogenous prostaglandins and microvascular permeability. Phytomedicine 3, 327-333.

Ankli, A., Sticher, O., Heinrich, M., 1999. Medical Ethnobotany of the Yucatec Maya: healers' consensus as a quantitative criterion. Economic Botany 53, 144-160.

Aparicio, A., Silvestre, S., 1987. Flora del parque natural de la Sierra de Grazalema, Junta de Andalucía, Agencia de Medio Ambiente. Universidad de Sevilla, Sevilla.

Arteche, A., Güenechea, J.I., Vanaclocha, B., 1994. Fitoterapia Vademecum de Prescripción. Plantas medicinales, third ed. Masson, Barcelona.

Barandiaran, J.M., Manterola, A., 1990. La alimentación doméstica en Vasconia. Eusko Jaurlaritza, Etniker Euskalerria, Bilbao.

Benito, P.B., Abad, M.J., Díaz Lanza, A.M., Villaescusa, L., González, M.A., Silván, A.M., 2002. Sesquiterpenes from Jasonia glutinosa: in vitro anti-inflammatory activity. Biological and Pharmaceutical Bulletin $25,1-4$.

Bermejo, P., Cantó, P., Martín, M.S., 1995. Plantas medicinales de Prádena (Segovia), Diputación Provincial de Segovia, Segovia.

Blanco, E., 1996. El Caurel las plantas y sus habitantes, Fundación Caixa Galicia, Santiago de Compostela.

Blanco, E., 1998. Diccionario etnobotánico de Segovia, Ayuntamiento de Segovia, Caja Segovia, Segovia.

Blanco, E., 2002. Etnobotánica en los Montes de Toledo, Asociación Cultural Montes de Toledo, Toledo.

Blanco, E., Cuadrado, C., 2000. Etnobotánica en Extremadura, Estudio de La Calabria y La Siberia extremeñas, Madrid.

Bolòs, O., Vigo, J., 1984-2001. Flora dels Països Catalans, vol. I-IV, Barcino, Barcelona.

Bonafé, F., 1980. Flora de Mallorca, vol. 4, Moll, Palma de Mallorca.

Bonet, M.A., 2001. Estudi etnobotànic del Montseny, Ph.D. Thesis, Facultat de Farmàcia, Universidad de Barcelona, Barcelona.

Bonet, M.A., Parada, M., Selga, A., Vallès, J., 1999. Studies on pharmaceutical Ethnobotany in the regions of L'Alt Empordà and Les Guilleries (Catalonia, Iberian Peninsula). Journal of Ethnopharmacology $68,154-168$.

Bonet, M.A., Vallès, J., 2002. Use of non-crop food vascular plants in Montseny biosphere reserve (Catalonia, Iberian Peninsula). International Journal of Food Sciences and Nutrition 53, 225-248.

Brullo, S., 1979. Taxonomic and nomenclatural notes on the genera Jasonia Cass. and Chiliadenus Cass. (Compositae). Webbia 34, 289-308.

Bruneton, J., 1999. Pharmacognosy, Phytochemistry: Medicinal Plants, second ed. Lavoisier Publishing, Paris.

Calero, J.L., 1989. Nombres vernáculos de la flora conquense, Ayuntamiento de Cuenca, Cuenca.

Casado, D., 2003. Revisión de la flora y etnobotánica de la campiña de Jaén: (del Guadalbullón a la Cuenca del Salado de Porcuna), Ph.D. Thesis, Universidad de Jaén, Departamento de Biología Animal, Vegetal y Ecología, Jaén.

Cavanilles, A.J., 1802. Descripción de las plantas que D. Antonio Josef Cavanilles demostró en las lecciones públicas del año 1801, precedida de los principios elementales de la Botánica, Imprenta Real, Madrid.

Ceballos, L., 1965. Flora del Quijote, Real Academia de la Lengua, Madrid.

Cervantes, M., 1941. Obras completas, Espasa Calpe, Madrid.

Cienfuegos, B., around 1620. Historia de yerbas y plantas, Manuscripts 3357-3363, Biblioteca Nacional, Madrid.

Climent, D., 1992. Les nostres plantes (Una aproximació multidisciplinar al món vegetal de les nostres terres), Aguaclara, Alicante. 
Colmeiro, M., 1871. Diccionario de los diversos nombres vulgares de muchas plantas usuales o notables del Antiguo y Nuevo Mundo, con la correspondencia científica y la indicación abreviada de los usos e igualmente de la familia a que pertenece cada planta, Madrid.

Colmeiro, M., 1885-1895. Enumeración y revisión de las plantas de la Península Hispano-Lusitánica e Islas Baleares, con la distribución geográfica de las especies y sus nombres vulgares, tanto nacionales como provinciales, Madrid.

Colmeiro, M., 1895. Noticia sucinta de los animales y plantas que mencionó Cervantes en El Quijote, con nociones históricas acerca del tabaco, chocolate, café y té, cuyo uso no conoció el ingenioso hidalgo, Madrid.

Dharmananda, S., 2001. Safety issues affecting herbs: pyrrolizidine alkaloids, Available at http://www.itmonline.org/arts/pas.htm.

Esgueva, M.A., 1999. Las plantas silvestres en León, Estudio de Dialectología Lingüística, Universidad Nacional de Educación a Distancia, Madrid.

Esteban, J., 1995. Análisis de componentes volátiles en plantas por desorción térmica automática y cromatografía de gases, Ph.D. Thesis, Universidad Complutense de Madrid, Madrid.

Etkin, N.L., 1996. Medicinal cuisines: diet and ethnopharmacology. International Journal of Pharmacognosy 34, 313-326.

Fajardo, J., Verde, A., Rivera, D., Obón, C., 2000. Las plantas en la cultura popular de la provincia de Albacete, Instituto de Estudios Albacetenses, Diputación de Albacete, Albacete.

Fernández Ocaña, A.M., 2000. Estudio etnobotánico en el Parque Natural de las Sierras de Cazorla, Segura y las Villas. Investigación química de un grupo de especies interesantes, Ph.D. Thesis, Facultad de Ciencias Experimentales, Universidad de Jaén, Jaén.

Ferrández, J.V., Sanz, J.M., 1993. Las plantas en la medicina popular de la Comarca de Monzón (Huesca), Instituto de Estudios Altoaragoneses, Diputación de Huesca, Huesca.

Figuerola, R., Peris, J.B., Stübing, G., 1988. Guía de las flores silvestres de la Comunidad Valenciana, Consorci d'Editors Valencians, Mestral, Valencia.

Font Quer, P., 1962. Plantas medicinales, El Dioscórides renovado, Labor, Barcelona.

Furlenmeier, M., 1984. Plantas curativas y sus propiedades medicinales, Schwitter, Zug.

Fresquet, J.L., Blanquer, G., Galindo, M., Gallego, F., García de la Cuadra, R., López Bueno, J.A., Sanjosé, A., 2001. Inventario de plantas medicinales de uso popular en la ciudad de Valencia. Medicina y Ciencias Sociales 13, Available at http://www.uv.es/medciensoc/.

Gadow, H., 1897. In Northern Spain. Adam and Charless Black, London.

Gil Pinilla, M., 1995. Estudio etnobotánico de la flora aromática y medicinal del término municipal de Cantalojas (Guadalajara), Ph.D. Thesis, Facultad de Ciencias Biológicas, Universidad Complutense de Madrid, Madrid.

González-Tejero, M.R., 1990. Investigaciones etnobotánicas en la provincia de Granada, Ph.D. Thesis, Facultad de Farmacia, Universidad de Granada, Granada.

Guzmán Tirado, M.A., 1997. Aproximación a la etnobotánica de la provincia de Jaén, Ph.D. Thesis, Departamento de Biología Vegetal, Universidad de Granada, Granada.

Heinrich, M., 2000. Ethnobotany and its role in drug development. Phytotherapy Research 14, 479-488.

Kaya, A., Baser, K.H.C., Demirci, B., Koca, F., 1999. The essential oil of Acinos alpinus (L.) Moench growing in Turkey. Flavour and Fragrance Journal 14, 55-59.

Kazuko, O., 1944. El libro del té, Ánfora, Barcelona.

Laguna, A., 1555. Pedacio Dioscorides Anazarbeo, Acerca de la materia medicinal y de los venenos mortíferos, Translated from the Greek and illustrated by Dr. Andrés de Laguna, Facsimil edition (1991) of Consejería de Agricultura y Cooperación de la Comunidad de Madrid, Madrid.

Lange, D., 1998. Europe's medicinal and aromatic plants: their use, trade and conservation. Traffic International, Cambridge, United Kingdom.
Lastra, J.J., 2003. Etnobotánica en el Parque Nacional de Picos de Europa, Ministerio de Medio Ambiente, Parques Nacionales, Oviedo.

l'Écluse, C. de (Clusius), 1576. Rariorum aliquot stirpium per Hispanias observatarum historia, C. Plantin, Antwerp.

Leonti, M., Sticher, O., Heinrich, M., 2003. Antiquity of medicinal plant usage in two Macro-Mayan ethnic groups (Mexico). Journal of Ethnopharmacology 88, 119-124.

Loscos, F., Pardo, J., 1867. Tratado de plantas de Aragón, Semanario Farmacéutico, Madrid.

Martín-Aragón, F.J., 1998. Los saberes médicos en "La Celestina", Diputación Provincial de Toledo, Toledo.

Martínez Lirola, M.J., González-Tejero, M.R., Molero, J., 1997. Investigaciones etnobotánicas en el Parque Natural de Cabo de Gata-Níjar (Almería), Sociedad Almeriense de Historia Natural, Consejería de Medio Ambiente, Junta de Andalucía, Almería.

Masclans, F., 1981. Els noms de les plantes als Paisos Catalans, Montblanc-Martin, C.E.C., Granollers.

Mateo, G., 1990. Catálogo florístico de la provincia de Teruel, Instituto de Estudios Turolenses, Diputación Provincial de Teruel, Teruel.

Mesa, S., 1996. Estudio etnobotánico y agroecológico de la Comarca de la Sierra de Mágina (Jaén), Ph.D. Thesis, Universidad Complutense de Madrid, Madrid.

Molina Mahedero, N., 2001. Estudio de la flora de interés etnobotánico en el municipio de Carcabuey (Córdoba), Graduate Thesis, Escuela Técnica Superior de Ingenieros Agrónomos y Montes, Universidad de Córdoba, Córdoba.

Mulet, L., 1991. Estudio etnobotánico de la provincia de Castellón, Diputación de Castellón, Castellón.

Muntané, J., 1994. Tresor de la saviesa popular de les herbes, remeis i creences de Cerdanya del temps antic, Institut d'Estudis Ceretans, Puigcerdà, Girona.

Muñoz, L.M., 2003. Plantas medicinales españolas: Jasonia glutinosa (L.) DC. (Asteraceae) (Té de roca). Acta Botanica Malacitana 28, 221-227.

Obón, C., Rivera, D., 1991. Las plantas medicinales de nuestra region, Editora regional, Agencia Regional del Medio Ambiente, Murcia.

Oria de Rueda, J.A., Díez, J., Rodríguez, M., 1996. Guía de las plantas silvestres de Palencia, Cálamo, Palencia.

Ortuño, I., 2003. Etnobotánica de los Villares y Valdepeñas de Jaén (Sur de la Península Ibérica), Ph.D. Thesis, Departamento de Biología Animal, Vegetal y Ecología, Universidad de Jaén, Jaén.

Palau, A., 1784-1788. Parte práctica de botánica del caballero Carlos Linneo: que comprehende las clases, órdenes, géneros, especies y variedades de las plantas, con sus caracteres genéricos y específicos, sinónimos más selectos, nombres triviales, lugares donde nacen, y propiedades, Translated from Latin into Castilian and illustrated by Antonio Paláu y Verdéra, Madrid.

Panero, J.A., Sánchez, C., 2000. Sayago, Costumbres, creencias y tradiciones, PRODER, Unión Europea, Junta de Castilla y León, Diputación de Zamora, Sayago.

Parada, M., Selga, A., Bonet. M.A., Vallès, J., 2002. Etnobotànica de les terres gironines: natura i cultura popular a la plana interior de l'Alt Empordà i a les Guilleries, Diputació de Girona, Girona.

Pardo de Santayana, M., 2003. Las plantas en la cultura tradicional de la Antigua Merindad de Campoo, Ph.D. Thesis, Facultad de Ciencias, Departamento de Biología, Universidad Autónoma de Madrid, Madrid.

Pardo de Santayana, M., Gómez Pellón, E., 2003. Etnobotánica: aprovechamiento tradicional de plantas y patrimonio cultural. Anales del Jardín Botánico de Madrid 60, 171-182.

Pardo de Santayana, M., Morales, R., 2004. Consideraciones sobre el género Jasonia (Compositae, Inuleae). Sistemática y usos. Acta Botanica Malacitana 29, 221-232.

Pellicer, J., 2000. Costumari botanic, Recerques etnobotàniques a les comarques centrals valencianes, Edicions del Bullent, Picanya, Valencia.

Pérez de Paz, P.L., Medina, I., 1988. Catálogo de plantas medicinales de la Flora Canaria. Aplicaciones populares, Instituto de Estudios Canarios, CSIC, La Laguna. 
Peris, J.B., Stübing, G., Romo, A., 2001. Plantas medicinales de la Península Ibérica e Islas Baleares, Jaguar, Madrid.

Pieroni, A., 2000. Medicinal plants and food medicines in the folk traditions of the Upper Lucca Province, Italy. Journal of Ethnopharmacology 70, 235-273.

Quer, J., 1762-1764. Flora española o historia de las plantas que se crían en España, vols. 1-4, Ibarra, Madrid. Continued by C. Gómez-Ortega, 1784 , vols. 5-6.

Rabal, G., 2000. Cuando la chicoria echa flor.... Etnobotánica en Torre Pacheco. Revista Murciana de Antropología 6, 1-240.

Ramón-Laca, L., 2003. The introduction of cultivated Citrus to Europe via northern Africa and the Iberian Peninsula. Economic Botany 57, 502-514.

Rivera, D., Obón, C., Cano, F., Robledo, A., 1994. Introducción al mundo de las plantas medicinales en Murcia, Ayuntamiento de Murcia, Murcia.

Rodríguez Lion, M.L., 1997. Aislamiento e identificación de compuestos polifenólicos en Sideritis hyssopifolia subp. hyssopifolia L. Contribución a su estudio farmacológico, Ph.D. Thesis, Universidad de Alcalá de Henares, Madrid.

Rodríguez Lyon, M.L., Díaz Lanza, A.M., Bernabé, M., Villaescusa, L., 2000. Flavone glycosides containing acetylated sugars from Sideritis hyssopifolia. Magnetic Resonance in Chemistry 38, 684-687.

Romero, M.A.G., Castillo, L.V., Lanza, A.M.D., Bricio, J.M.A., Monzón, C.A.S., Perucha, J.S., 2003. Volatile composition of Jasonia glutinosa DC. Zeitschrift für Naturforschung 58, 804-806.

San Miguel, E., 2004. Etnobotánica de Piloña (Asturias). Cultura y saber popular sobre las plantas en un concejo del Centro-Oriente Asturiano, Ph.D. Thesis, Facultad de Ciencias, Departamento de Biología, Universidad Autónoma de Madrid, Madrid.

Saule, M., 1991. La grande flore illustrée des Pyrenees, Randonnees Pyrénéennes, Editions Milan.

Scarpa, G., 2004. Medicinal plants used by the Criollos of northwestern Argentine Chaco. Journal of Ethnopharmacology 61, 115-135.

Tardío, J., Pascual, H., Morales, R., 2002. Alimentos silvestres de Madrid, La Librería, Madrid.
Trotter, R., Logan, M., 1986. Informant consensus: a new approach for identifying potentially effective medicinal plants. In: Etkin, N.L. (Ed.), Plants in Indigenous Medicine and Diet: Biobehavioural Approach. Redgrave Publishers, Bedford Hills, New York, pp. 91112.

Velasco-Negueruela, A., Perez-Alonso, M.J., Jiménez, S.M., García, F.M., 1993. The volatile constituents of Acinus alpinus (L.) Moench ssp. meridionalis (Nyman), P.W. Ball growing in Spain. Flavour and Fragrance Journal 8, 127-130.

Verde, A., 2003. Estudio etnofarmacológico de tres áreas de montaña de Castilla-La Mancha, Ph.D. Thesis, Facultad de Biología, Universidad de Murcia, Murcia.

Verde, A., Fajardo, J., Rivera, D., Obón, C., 2000. Etnobotánica en el entorno del Parque Nacional de Cabañeros, Parques Nacionales, Secretaría General de Medio Ambiente, Ministerio de Medio Ambiente, Madrid.

Verde, A., Rivera, D., Obón, C., 1998. Etnobotánica en las sierras de Segura y Alcaraz: las plantas y el hombre, Instituto de Estudios Albacetenses, Diputación de Albacete, Albacete.

Villaescusa, L., Díaz-Lanza, A.M., Gasquet, M., Delmas, F., Ollivier, E., Bernabé, M., Faure, R., Elias, R., Balansard, G., 2000. Antiprotozoal activity of sesquiterpenes from Jasonia glutinosa. Pharmaceutical Biology $38,176-180$.

Villar, L., 2003. Los saberes científico y popular en torno a las plantas del Pirineo Aragonés. Un ejemplo de biodiversidad cultural. Monografías de la Real Academia de las Ciencias Exactas, Físicas., Químicas y Naturales de Zaragoza 23, 1-42.

Villar, L., Palacín, J.M., Calvo, C., Gómez, D., Monserrat, G., 1987. Plantas medicinales del Pirineo aragonés y demás tierras oscenses, CSIC, Diputación de Huesca, Huesca.

Villar, L., Sessé, J.A., Ferrández, J.V., Palacín, J.M., 2001. Atlas de la flora del Pirineo Aragonés, vol. II (Pyrolaceae-Orchidaceae. Síntesis), Consejo de Protección de la Naturaleza de Aragón, Instituto de Estudios Altoaragoneses, Departamento de Agricultura y Medio Ambiente del Gobierno de Aragón, Instituto Pirenaico de Ecología (CSIC), Huesca. 